Article

\title{
Increase in Oxidation Resistance of MAR M-509 via LA-CVD Aluminizing
}

\author{
Wojciech J. Nowak*(D), Bernadeta Hader, Kamil Ochał (D) and Bartek Wierzba \\ Department of Materials Science, Faculty of Mechanical Engineering and Aeronautics, \\ Rzeszow University of Technology, Powstanców Warszawy 12, 35-959 Rzeszów, Poland; \\ bernadetah5@gmail.com (B.H.); kochal@prz.edu.pl (K.O.); bwierzba@prz.edu.pl (B.W.) \\ * Correspondence: wjnowak@prz.edu.pl; Tel.: +48-17-743-2375
}

Citation: Nowak, W.J.; Hader, B.; Ochał, K.; Wierzba, B. Increase in Oxidation Resistance of MAR M-509 via LA-CVD Aluminizing. Coatings 2021, 11, 1306. https://doi.org/ 10.3390/coatings11111306

Academic Editor: Alessandro Patelli

Received: 30 September 2021

Accepted: 26 October 2021

Published: 27 October 2021

Publisher's Note: MDPI stays neutral with regard to jurisdictional claims in published maps and institutional affiliations.

Copyright: (c) 2021 by the authors. Licensee MDPI, Basel, Switzerland. This article is an open access article distributed under the terms and conditions of the Creative Commons Attribution (CC BY) license (https:// creativecommons.org/licenses/by/ $4.0 /)$.

\begin{abstract}
Due to their excellent mechanical properties, Co-based alloys are one of the main candidates to replace Ni-based alloys in high temperature application. Knowledge about oxidation resistance of Co-based alloy MAR M-509 and the extent of its aluminizing on its oxidation resistance is limited. Therefore, in the present study, an aluminide layer was manufactured by low activity chemical vapor deposition (LA-CVD) on MAR M-509. Aluminized and uncoated alloys were investigated in terms of oxidation kinetics and oxidation resistance during isothermal and cyclic oxidation at 1000 and $1100{ }^{\circ} \mathrm{C}$. Material in the as-cast and after exposure was analyzed using scanning electron microscopy (SEM), thermogravimetry (TG) and glow-discharge optical emission spectrometry (GDOES). Obtained results allowed for elucidating of degradation mechanism including nitridation process of carbides for MAR M-509. It was found that aluminizing of MAR M-509 significantly decreases its oxidation kinetics by the factor of 2.5 and 1.5 at 1000 and $1100{ }^{\circ} \mathrm{C}$ respectively. Moreover, the suppression of identified degradation mechanism in case of aluminized alloy was found until occurrence of breakaway oxidation of the aluminide layer. It was also proposed that further increase in oxidation resistance can be successively achieved by an increase in aluminide layer thickness.
\end{abstract}

Keywords: high temperature oxidation; MAR M-509; aluminide layer; breakaway oxidation; oxidation mechanism

\section{Introduction}

Alloys used in aircraft engines or in stationary gas turbines (SGT) face harsh conditions, such as high temperature, aggressive gases and cyclic thermal loading. Thus, they need to possess good combinations of mechanical strength, microstructural stability and oxidation resistance. Ni-based alloys are the most common materials used in the hottest part of the gas turbines nowadays. However, the constant need of increase in gas turbines efficiency demands increasing of inlet gases temperature [1]. This in turn implies difficulties due to material limitation, which is mainly its melting temperature. Thus, the research for novel materials for application at high temperature is required. To ensure increased oxidation resistance, the protective coatings are applied on the surface of elements manufactured from Ni-based alloys, such as aluminide layers [2-5], MCrAlY-type coatings [6-9] or complete thermal barrier coatings (TBC) [10-13]. However, the research for alternative materials for potential replacement of Ni-based alloys is still required. The so-called high entropy alloys (HEAs) are promising candidates to replace Ni-based alloys in the hottest parts of gas turbines [14-17]. The proposed materials are TiAl alloys [18-20], $\mathrm{MoSi}_{2}$-based alloys or their composites [21-23] or Co-based alloys [24-26]. The major advantage of a Co-based alloy in comparison with Ni-based alloys are their better mechanical properties [27], higher melting temperature [28] and high resistance against corrosion and sulfidation [29,30]. Studies on oxidation behavior of Co-based superalloys revealed that they possess relatively high oxidation resistance [31-35]. It is known that aluminide layers increase high temperature oxidation of Ni-based alloys. Therefore, several attempts were made to produce aluminide 
layers on Co-based alloys, e.g., on Haynes 188 and WI-52 [36], and also to study the oxidation resistance of alloys such as AMS 5608 with an aluminide layer produced by pack-cementation [37] or DZ40M with aluminide layer made by low pressure chemical vapor deposition (LP-CVD) [38]. Among Co-based alloys, the family MAR M-509 is one of the most popular for high-temperature application. It is characterized by good mechanical properties, such as fatigue strength [39], thermomechanical fatigue [40,41] and good corrosion and erosion resistance [42]. However, studies on oxidation behavior of MAR M-509 are scant [43]. Moreover, no studies on the effect of aluminizing on oxidation resistance of MAR M-509 were done so far. Therefore, to fulfil this lack, the present study was done. In the present study, the oxidation behavior of an aluminized and uncoated MAR M-509 during isothermal and cyclic oxidation tests at $1000{ }^{\circ} \mathrm{C}$ and $1100{ }^{\circ} \mathrm{C}$ was conducted and compared.

\section{Materials and Methods}

In the present study, a Co-based superalloy MAR M-509, with the chemical composition given in Table 1, was investigated in terms of high temperature oxidation resistance. The chemical composition of the studied alloy was measured using spark emission optical spectrometer (Spark-OES) ARL 3460 made by Thermo Fisher Scientific (Ecublens, Switzerland). To study the extent of increase in the oxidation resistance, an aluminide layer on MAR M-509 via the low activity chemical vapor deposition (LA-CVD) method was manufactured using BERNEX BPXpro 325S equipment (IHI BERNEX AG, Olten, Switzerland). The gaseous atmosphere consisting of a mixture of $\mathrm{AlCl} 3$ and $\mathrm{H} 2$ was produced in an external generator and transferred into a retort where samples were placed. The process was performed at $1040{ }^{\circ} \mathrm{C}$ for $6 \mathrm{~h}$. The oxidation rate of aluminized and uncoated MAR M-509 was analyzed during isothermal thermogravimetrical oxidation test using XERION X-tube vertical furnace made by Xerion Advance Heating Ofentechchnik GmbH (Freiberg, Germany). The isothermal oxidation test was performed at two temperatures, namely 1000 and $1100^{\circ} \mathrm{C}$ in air for $48 \mathrm{~h}$. For determining the oxidation resistance during cyclic oxidation test, a furnace SCZ 120/150 made by Czylok (Jastrzębie Zdrój, Poland) was employed. The used thermal cycle consisted of $2 \mathrm{~h}$ heating at pre-set temperature and subsequent $15 \mathrm{~min}$ cooling with pressurized air. The mass change measurement was done every 10 cycles. After oxidation, the selected samples were subjected to an analysis of the element distribution as a function of sputtering time (indirectly depth) using glow discharge optical emission spectrometer (GD-OES) made by Horiba Jobin Yvon (Longjumeau, France). The GD-OES depth profiles were quantified using the procedure described in references [44-46]. The cross-sections of studied samples were produced using standard metallographic procedure, described elsewhere $[47,48]$. Microstructure and chemical composition of samples in the as-coated as well as after oxidation was investigated on surface and cross-sections using scanning electron microscope (SEM) Hitashi S3400N (Hitahi, Tokyo, Japan).

Table 1. Measured chemical composition of the studied alloy MAR M-509.

\begin{tabular}{cccccccccccc}
\hline Element & $\mathbf{C}$ & $\mathbf{N i}$ & $\mathbf{C r}$ & $\mathbf{W}$ & $\mathbf{T a}$ & $\mathbf{Z r}$ & $\mathbf{T i}$ & $\mathbf{F e}$ & Al & Si & Co \\
\hline Content in wt.\% & 0.55 & 9.82 & 22.88 & 6.89 & 3.79 & 0.35 & 0.18 & 0.16 & 0.25 & 0.05 & BAL. \\
\hline
\end{tabular}

\section{Results}

\subsection{Microstructure of MAR M-509 in the As-Cast Condition}

The microstructure of MAR M-509 in the as-cast condition is shown in Figure 1. As visible, the material reveals the presence of dendrtitic and interdendritic regions (Figure 1a). SEM/EDS elemental maps (Figure 2) showed that dendritic regions are enriched in $\mathrm{Co}, \mathrm{Cr}$ and $\mathrm{Ni}$, while in the interdendritic region, the bright precipitates are present (Figure 1b), which, based on SEM/EDS analysis, are Ta, Ti and Zr carbides (Figure 2). 


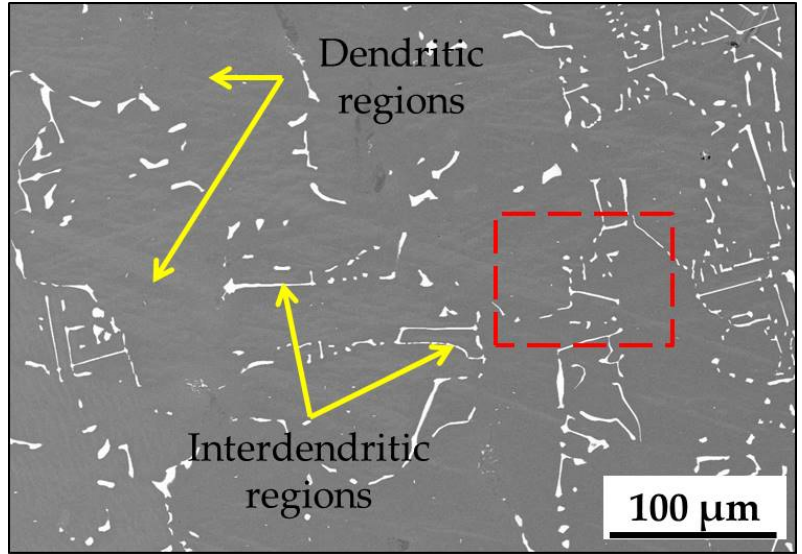

(a)

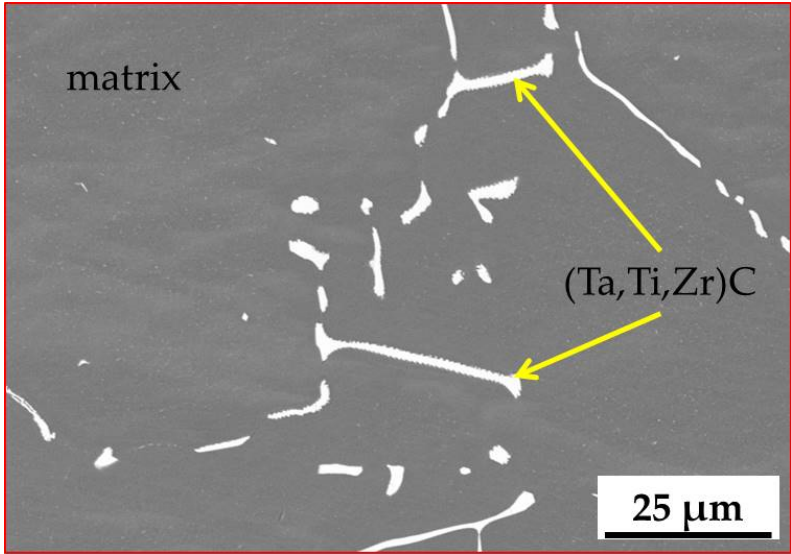

(b)

Figure 1. Microstructure of MAR M-509 in the as-cast conditions at (a) low magnification and (b) high magnification of the red-dashed box in figure (a).

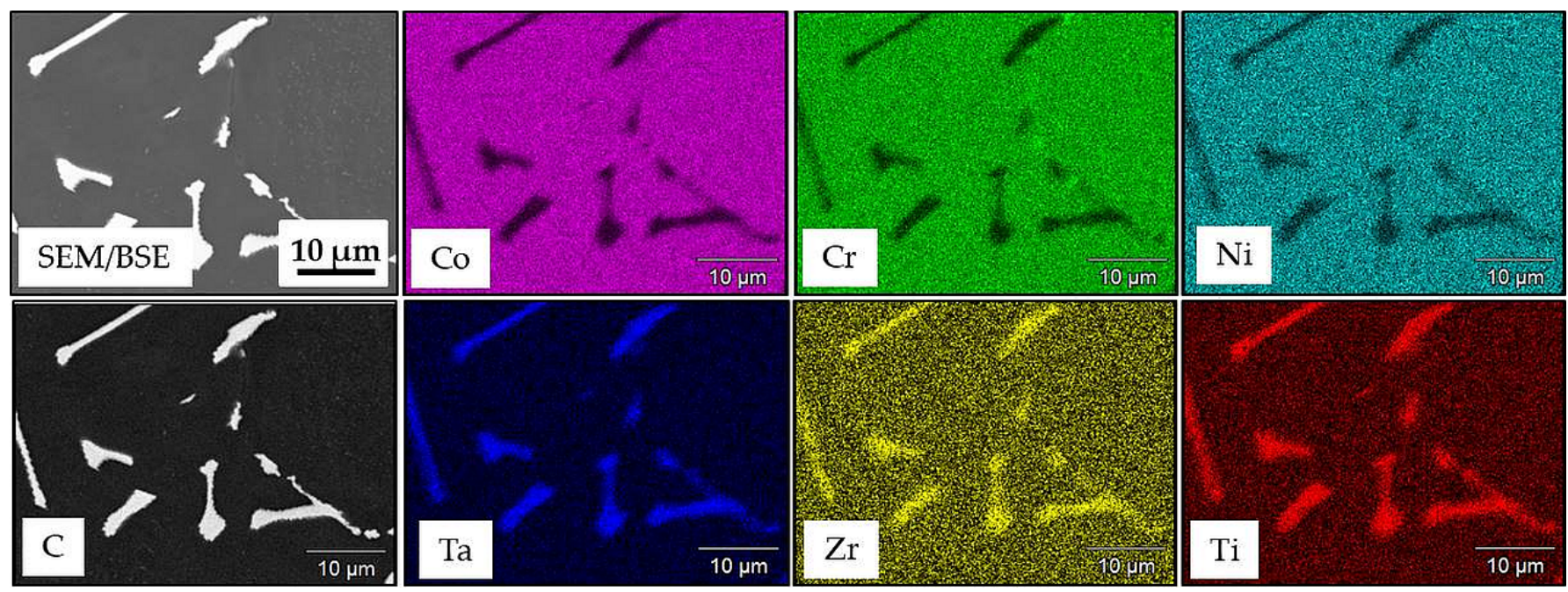

Figure 2. SEM/BSE elemental distribution maps obtained from MAR M-509 in the as-cast condition.

\subsection{Microstructure of MAR M-509 after CVD Aluminizing}

The microstructure of aluminide layer formed on the MAR M-509 substrate during the aluminizing process at $1040{ }^{\circ} \mathrm{C}$ for $6 \mathrm{~h}$ is shown in Figure 3. The observed microstructure is typical for LA-CVD layers and consists of the outer aluminide layer, the interdiffusion zone (IDZ) and the substrate (Figure 3a). The carbides are visible in the substrate zone. The aluminide layer was identified as CoAl. Within the aluminide layer a formation of aligned pores in the middle of aluminide layer is observed (Figure 3b). The average thickness of the formed aluminide CoAl layer is about $10 \mu \mathrm{m}$. The GD-OES depth profile shown in Figure 4 revealed that in the outer layer, a co-enrichment in $\mathrm{Co}$ and $\mathrm{Al}$ is observed up to about $110 \mathrm{~s}$ of stuttering. This co-enrichment confirms the formation of CoAl phase on surface of MAR M-509 substrate. At deeper parts, i.e., for a sputtering time between 110 and $300 \mathrm{~s}$, co-enrichment of $\mathrm{Cr}, \mathrm{C}$ and $\mathrm{W}$ is observed. The latter zone is called the interdiffusion zone (IDZ). Below the IDZ (for a sputtering time higher than $300 \mathrm{~s}$ ), the constant concentration of alloying elements is noted at the level of concentration in the base alloy. 


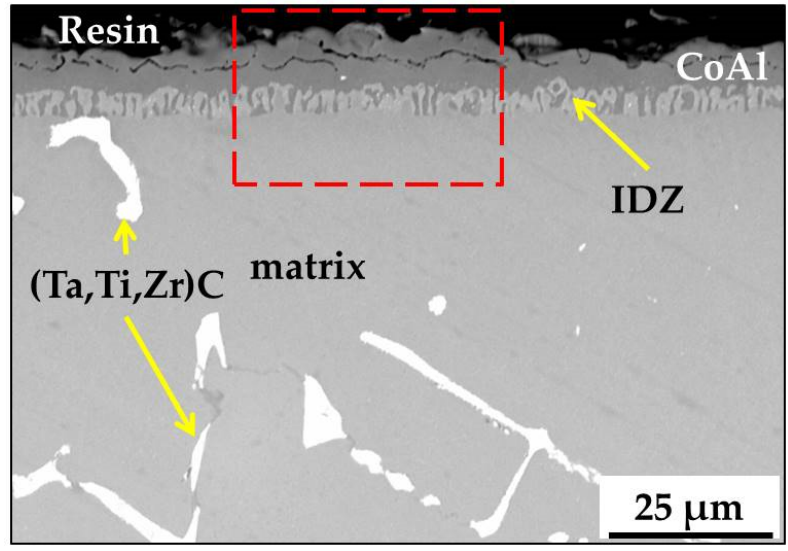

(a)

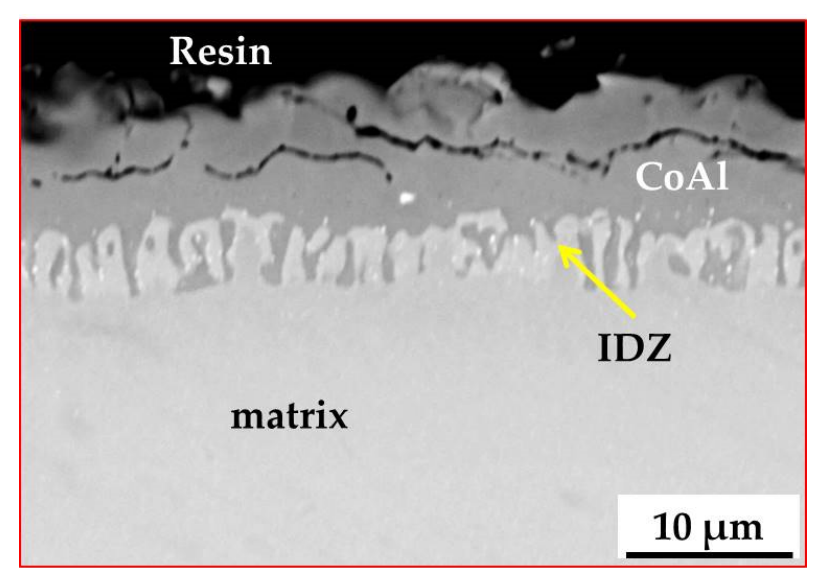

(b)

Figure 3. Microstructure of an aluminide coating on MAR M-509 taken at (a) low magnification and (b) high magnification of the red-dashed box in figure (a).

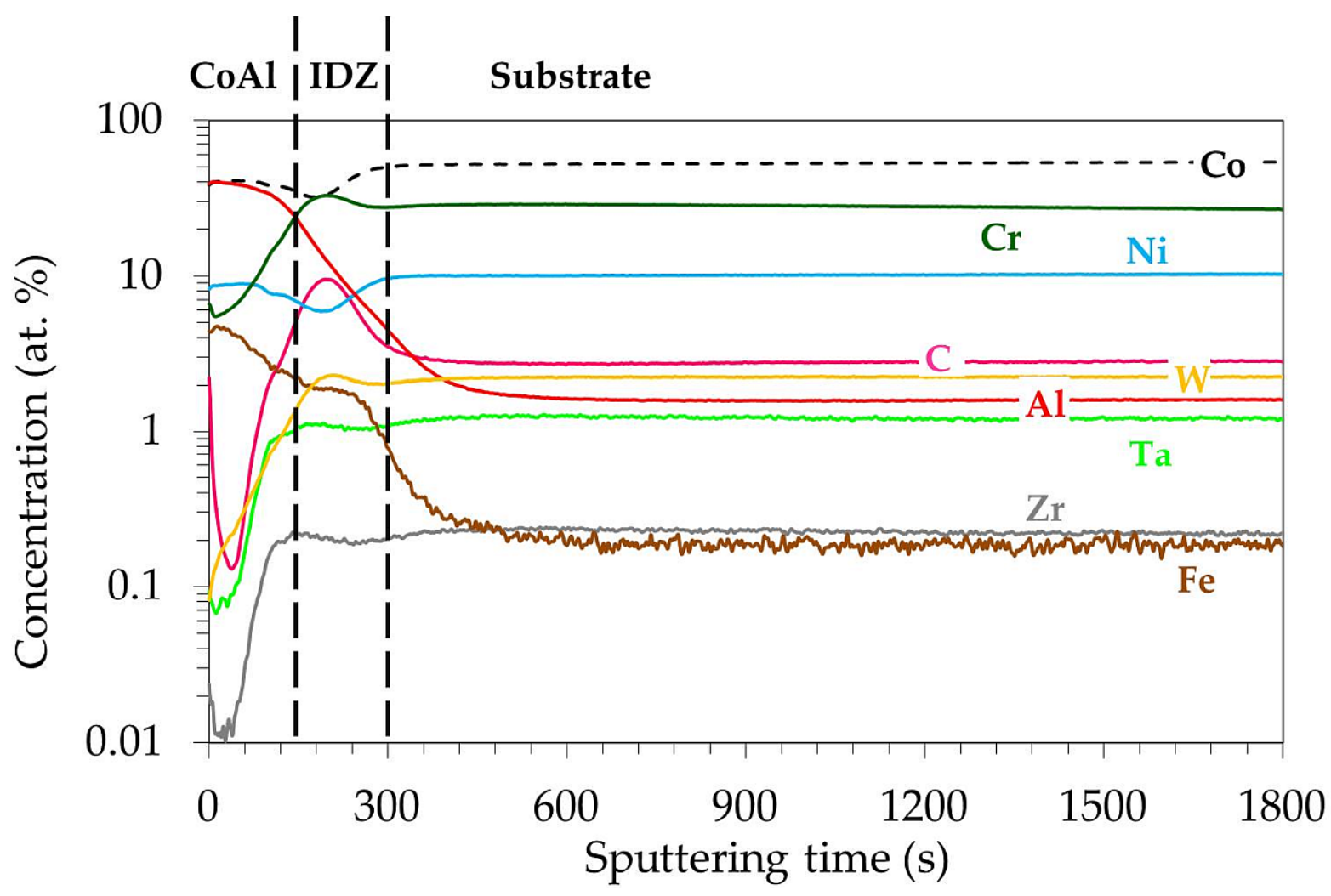

Figure 4. GD-OES depth profile of an aluminized MAR M-509.

3.3. Air Oxidation Tests at $1000^{\circ} \mathrm{C}$

3.3.1. Isothermal Oxidation Test

The mass change plots obtained for studied aluminized and uncoated MAR M-509 during isothermal air exposure at $1000^{\circ} \mathrm{C}$ showed the big difference between aluminized and uncoated material (Figure 5a). For uncoated MAR M-509, the measured mass change after $48 \mathrm{~h}$ of oxidation was equal to $1.3 \mathrm{mg} \cdot \mathrm{cm}^{-2}$, while for aluminized MAR M-509, mass change after $48 \mathrm{~h}$ of exposure was $0.06 \mathrm{mg} \cdot \mathrm{cm}^{-2}$. The logarithm of instantaneous oxidation rate $k^{\prime} w$, calculated on the basis of the mass change plots shown in Figure 5a for uncoated MAR M-509, was equal to -11 , while it was -13.5 for the aluminized one. 


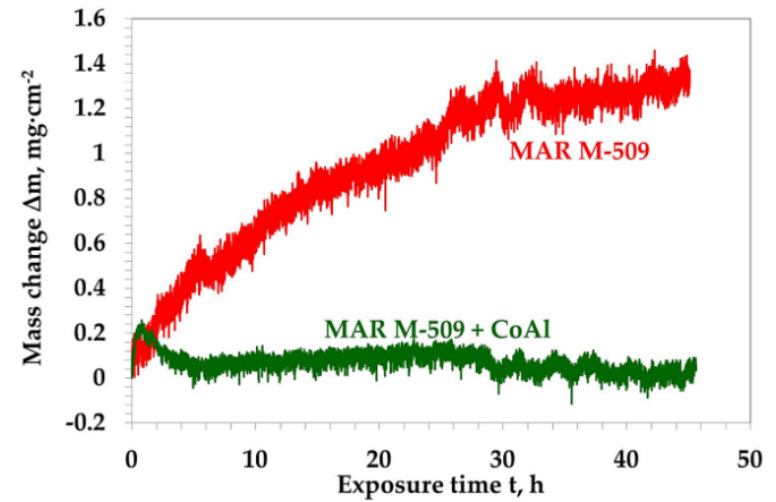

(a)

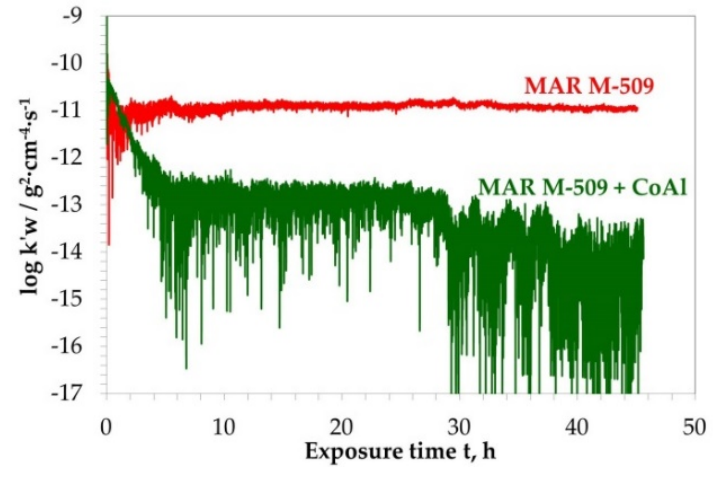

(b)

Figure 5. Mass change plot (a) and $\log \mathrm{k}^{\prime} \mathrm{w}(\mathbf{b})$ obtained during isothermal air oxidation at $1000{ }^{\circ} \mathrm{C}$ for $48 \mathrm{~h}$ of an aluminized MAR M-509 and reference alloy (uncoated MAR M-509).

Analysis of the surface of specimens after an isothermal oxidation test showed that the $\mathrm{Cr}_{2} \mathrm{O}_{3}$ oxide scale was formed on the surface of uncoated MAR M-509, while the formation of $\mathrm{Al}_{2} \mathrm{O}_{3}$ was observed (Figure 6a,b, respectively) on the surface of the aluminized alloy. An investigation of the cross section of uncoated MAR M-509 confirmed the formation of external chromia scale; however, formation of AlN below the oxide scale was observed (Figure 6c). On top of the aluminized MAR M-509, formation of the $\mathrm{Al}_{2} \mathrm{O}_{3}$ oxide scale was found. Below the external alumina scale, local formation of Al-depleted phase described as $\mathrm{Co}(\mathrm{Cr}, \mathrm{Ni}$ ) was observed (Figure $6 \mathrm{~d}$ ). The presence of IDZ and carbides is noted as well.

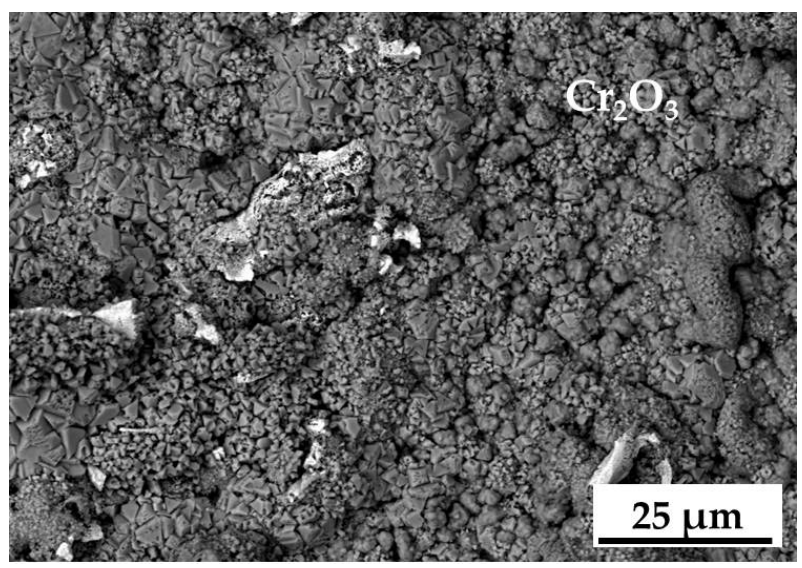

(a)

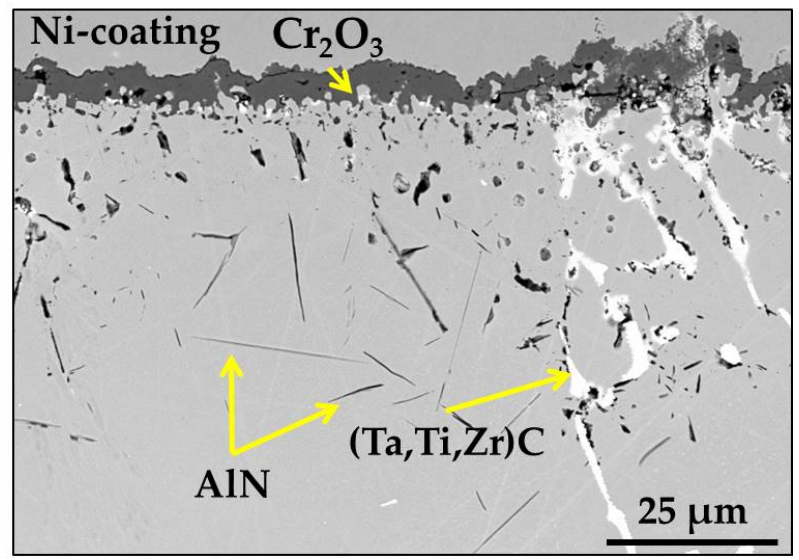

(c)

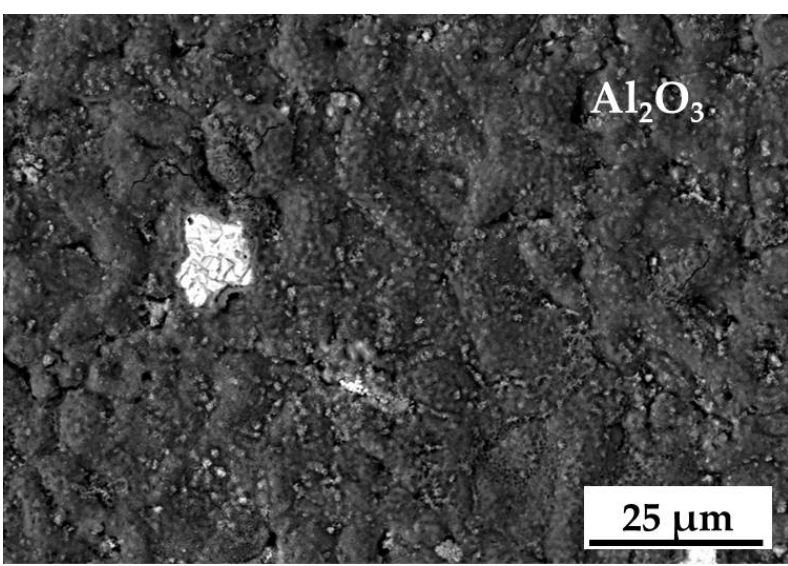

(b)

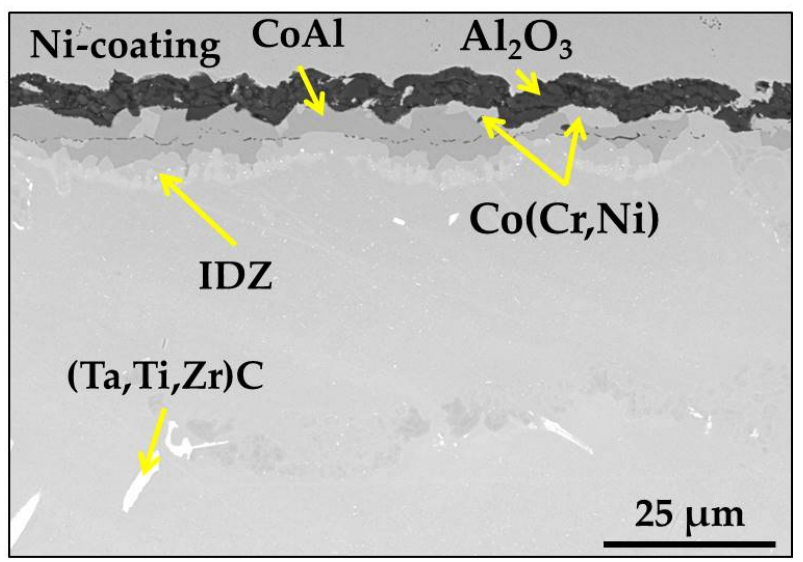

(d)

Figure 6. SEM/BSE images of surface of (a) MAR M-509 and (b) aluminized MAR M-509, with corresponding cross-sections of (c) MAR M-509 and (d) aluminized MAR M-509 after isothermal air oxidation at $1000^{\circ} \mathrm{C}$ for $48 \mathrm{~h}$. 


\subsubsection{Cyclic Oxidation Test}

Mass change plot obtained on aluminized and uncoated MAR M-509 during cyclic air oxidation test at $1000{ }^{\circ} \mathrm{C}$ is shown in Figure 7a. It is found that for uncoated alloy, the strong increase in mass change is observed up to about 400 cycles ( 800 hot hours). Above 400 cycles, a drop in mass change is observed. For aluminized MAR M-509, the constant increase in mass change is observed until the end of the cyclic oxidation test, i.e., up to 980 cycles (1960 hot hours-Figure 7a). However, the magnified mass change plot shown in Figure $7 \mathrm{~b}$ revealed that up to around 700 cycles, the slope of mass change curve observed for aluminized MAR M-509 changes from the slope marked by pink dashed line to the slope marked by brown dashed line (Figure 7b). SEM/EDS analysis of the surface of the exposed samples revealed that on top of uncoated MAR M-509, co-oxide was formed (Figure 8a), while on top of the aluminized alloy, formation of alumina scale is found (Figure $8 \mathrm{~b}$ ). Analysis of the cross-section of uncoated MAR M-509 showed that in the very outer part of the oxide scale, co-oxide is formed. Below the outer co-oxide layer, formation of $\mathrm{Co} / \mathrm{Cr} / \mathrm{Ni}$-mixed oxide is observed. Additionally, the intensive formation of AlN is visible (needle-like-shaped precipitates below the external oxide scale in Figure 8c). Formation of chromia scale was not observed. In the case of aluminized MAR M-509, formation of $\mathrm{Al}_{2} \mathrm{O}_{3}$ oxide scale on top of the remnants of the aluminide layer is found (Figure 8d). However, a local alumina scale spallation is noted (Figure 8b,d). Moreover, no presence of $\mathrm{CoAl}$ is observed, and only $\mathrm{Co}(\mathrm{Cr}, \mathrm{Ni})$ in the zone of aluminide layer is observed.

Macroscopic investigation of an aluminized MAR M-509 showed two types of regions on the sample surface. Namely, a grey colored region in the middle of the sample and blueish regions closer to the edge of the sample are found (marked by yellow arrow as "Breakaway oxidation" on Figure 9a. The latter is the indication of a so-called "breakaway oxidation" phenomenon. Figure $9 \mathrm{~b}$ shows the edge between the region where protective alumina oxide scale is formed and the region where "breakaway oxidation" occurred. The SEM/EDS elemental map shown in Figure 9c confirmed the formation of an alumina scale in the center of the sample (left side of images in Figure 9c), while in the region where "breakaway oxidation" occurred, enrichment of $\mathrm{Co}, \mathrm{Ni}$ and $\mathrm{Cr}$ is found (right-hand side of images in Figure 9c). Analysis of the cross-section of aluminized MAR M-509 in the region of breakaway showed a local destruction of $\mathrm{Al}_{2} \mathrm{O}_{3}$ (Figure 10a) and overgrowing of $\mathrm{Al}_{2} \mathrm{O}_{3}$ by chromia oxide scale (Figure 10b). Formation of chromia scale is accompanied by the occurrence of internal precipitates of $\mathrm{Al}_{2} \mathrm{O}_{3}$ (Figure 10b).

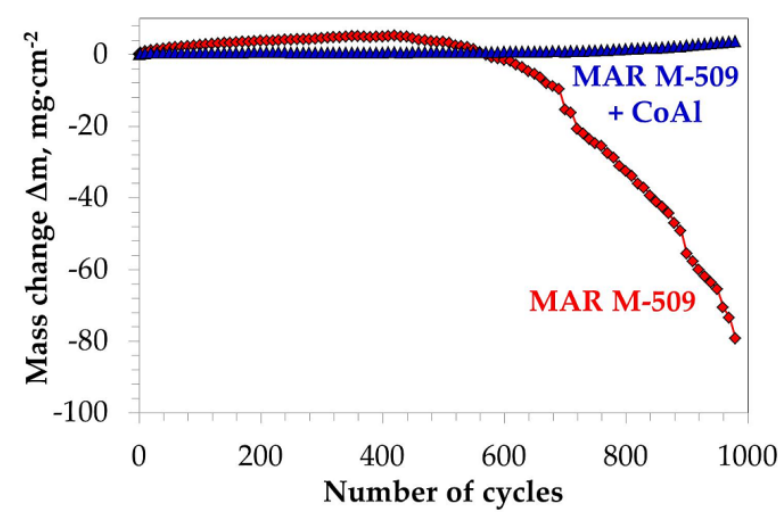

(a)

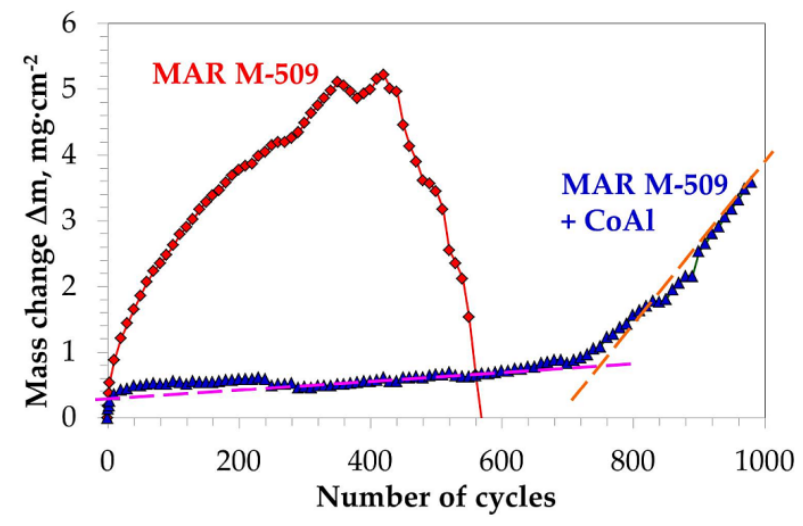

(b)

Figure 7. Mass change plot obtained during cyclic oxidation test at $1000{ }^{\circ} \mathrm{C}$ (a) and the enlarged part of the plot showing a change in the slope of curve obtained for an aluminized MAR M-509 (b). 


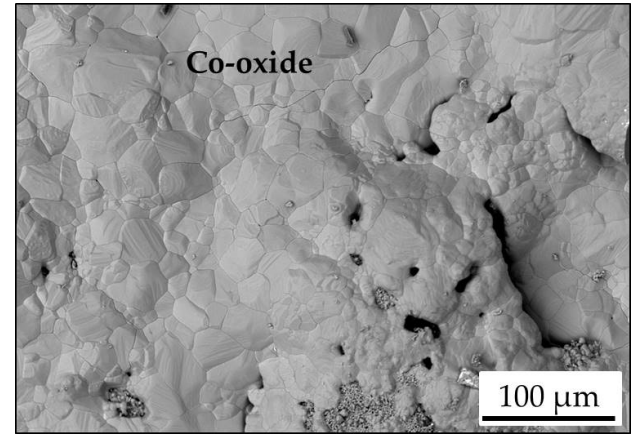

(a)

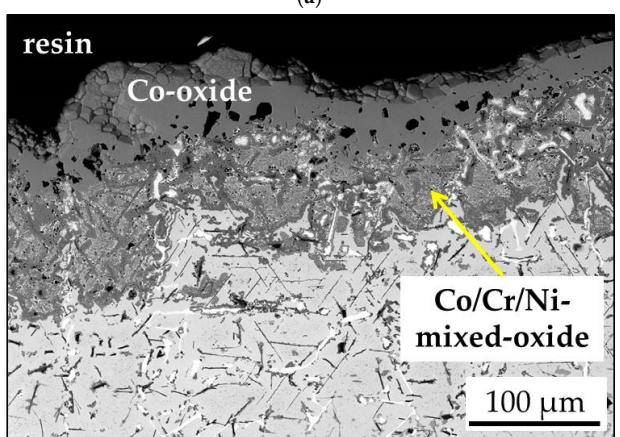

(c)

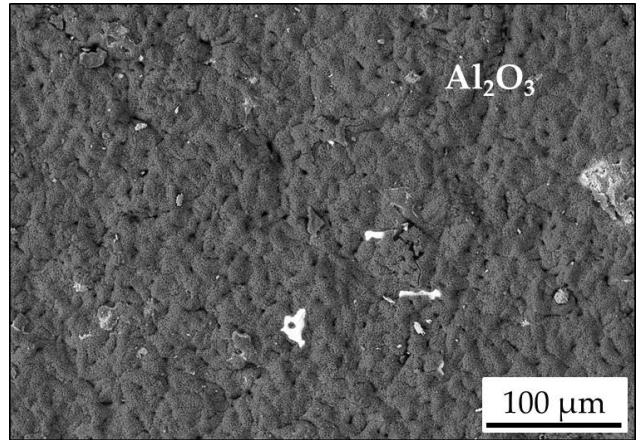

(b)

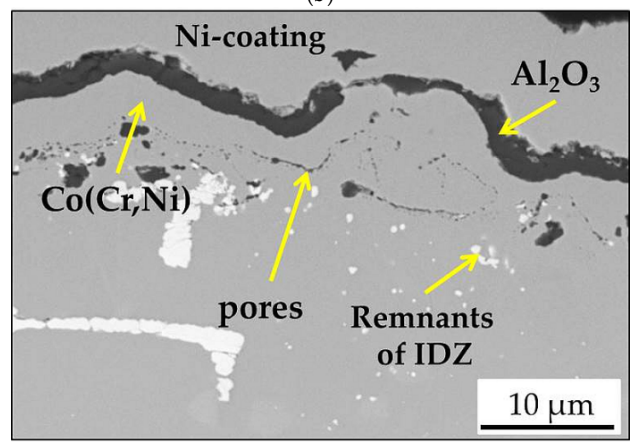

(d)

Figure 8. SEM/BSE images of surface of (a) MAR M-509 and (b) aluminized MAR M-509, with corresponding cross-sections of (c) MAR M-509 and (d) aluminized MAR M-509 after cyclic air oxidation at $1000^{\circ} \mathrm{C}$ for 1000 cycles.

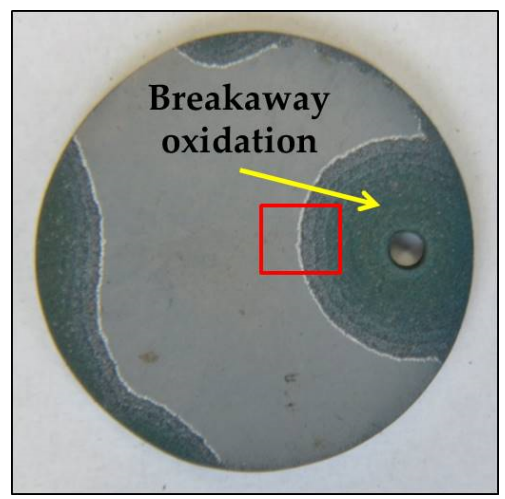

(a)

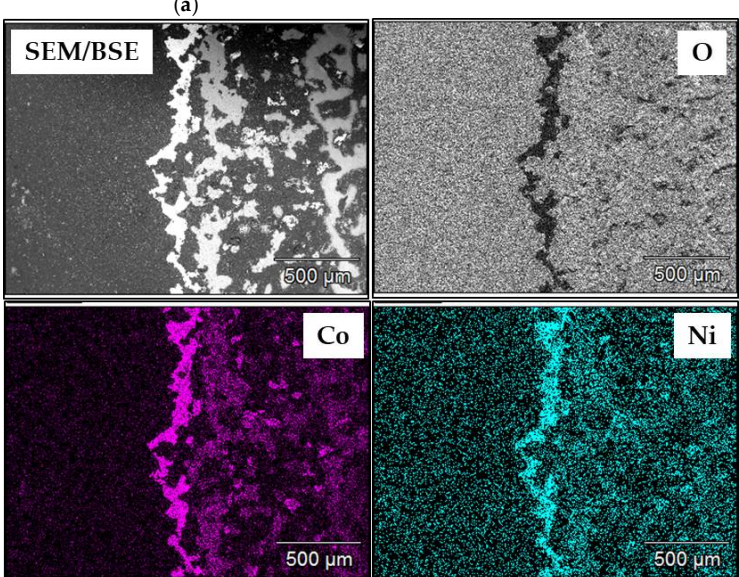

(c)

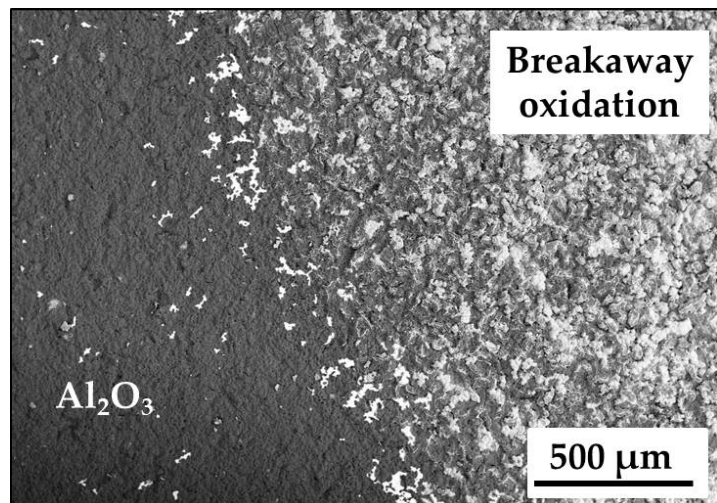

(b)

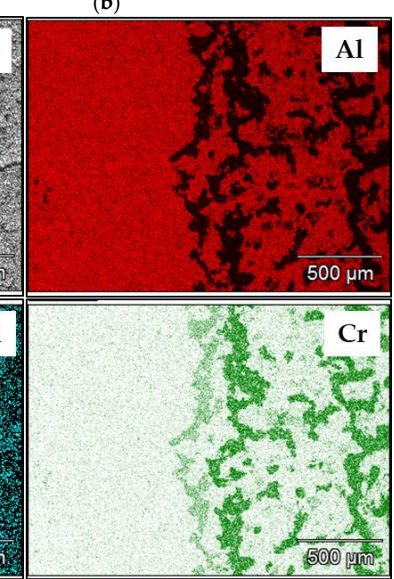

Figure 9. Images showing (a) the macroscopic picture of aluminized MAR M-509 after cyclic oxidation up to 1000 cycles, (b) the SEM/BSE image of surface at the border between region covered by protective oxide scale and breakaway oxidation and (c) the corresponding SEM/EDS elemental map from the aforementioned region. 


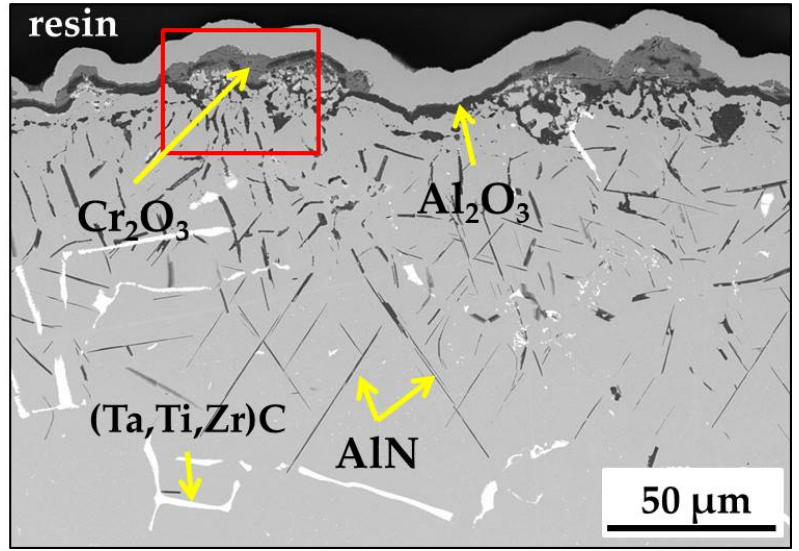

(a)

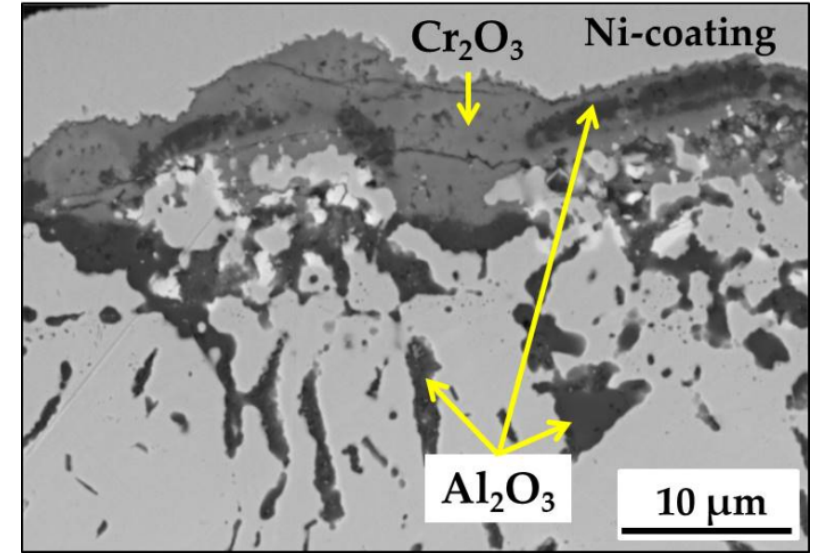

(b)

Figure 10. Microstructure of aluminized MAR M-509 in the region of breakaway occurrence shown at (a) low magnification and (b) high magnification.

\subsection{Air Oxidation Tests at $1100^{\circ} \mathrm{C}$}

\subsubsection{Isothermal Oxidation Test}

The mass change measured for uncoated and aluminized MAR M-509 during isothermal air oxidation at $1100{ }^{\circ} \mathrm{C}$ for $48 \mathrm{~h}$ is shown in Figure 11a. Uncoated MAR M-509 showed a rapid mass gain and the measured mass change after $48 \mathrm{~h}$ is $3.4 \mathrm{mg} \times \mathrm{cm}^{-2}$ and for aluminized alloy this is $0.7 \mathrm{mg} \times \mathrm{cm}^{-2}$ (Figure 11a). The logarithm of instantaneous oxidation rate $\mathrm{k}^{\prime} \mathrm{w}$ calculated on the basis of data shown in Figure 11a reached a value of -10 for uncoated alloy, while -11.6 for the aluminized one after $48 \mathrm{~h}$ of exposure.

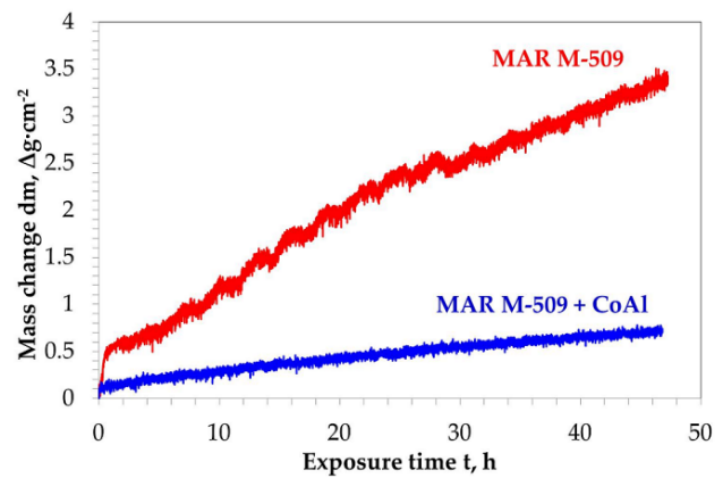

(a)

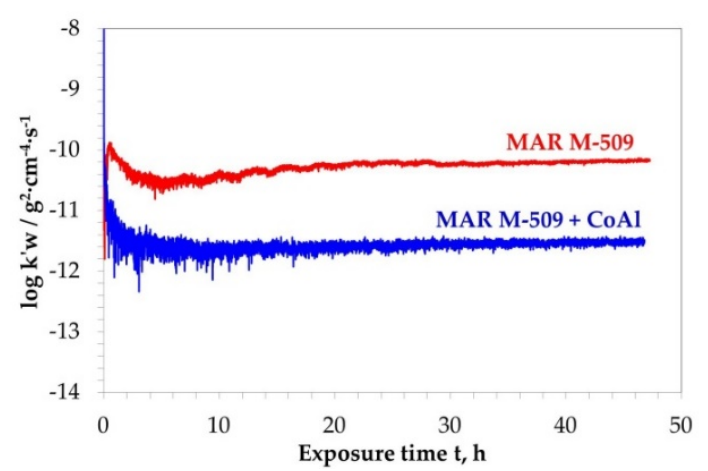

(b)

Figure 11. Mass change plot (a) and $\log \mathrm{k}^{\prime} \mathrm{w}(\mathbf{b})$ obtained during isothermal air oxidation at $1100^{\circ} \mathrm{C}$ for $48 \mathrm{~h}$ of an aluminized MAR M-509 and reference alloy (uncoated MAR M-509).

Analysis of the surface of uncoated MAR M-509 showed that the alloy formed $\mathrm{Cr}_{2} \mathrm{O}_{3}$ oxide scale; however, a number of places where spallation occurred can be found (Figure 12a). In the case of aluminized MAR M-509 after isothermal air exposure at $1100{ }^{\circ} \mathrm{C}$ for $48 \mathrm{~h}$ formation of $\mathrm{Al}_{2} \mathrm{O}_{3}$ oxide scale is observed; however, many places of its spallation are also found (Figure 12b). SEM/BSE image of the cross-section of uncoated alloy after exposure is shown in Figure 12c. It is visible that the chromia scale is formed on the surface of the sample; however, several cracks formed within the external chromia scale (Figure 12c). On the cross-section of an aluminized MAR M-509, the remnants of alumina scale on top of the aluminide layer can be found as well as places where the alumina scale spalled off (Figure 12d). It is also visible that the aluminide layer no longer consists of $\mathrm{CoAl}$, but rather $\mathrm{Co}(\mathrm{Al})$. The remnants of IDZ can still be found below the $\mathrm{Co}(\mathrm{Cr}, \mathrm{Ni})$ layer. 


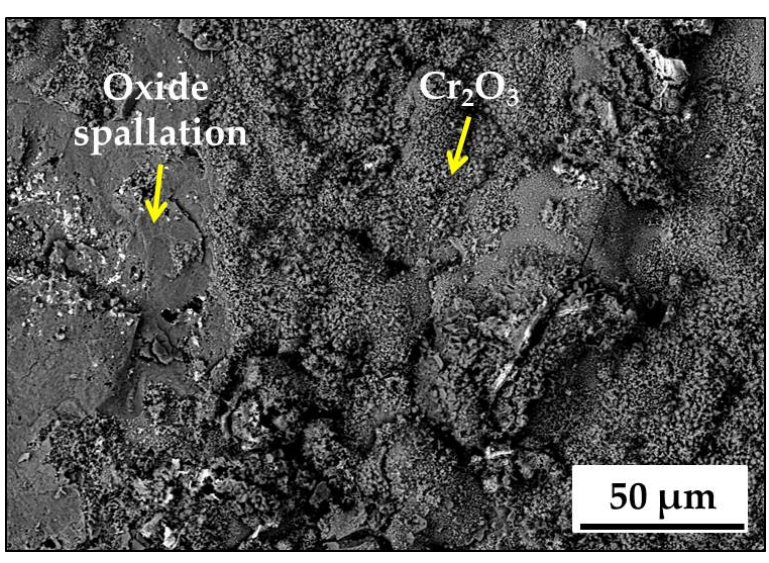

$(\mathbf{a})$

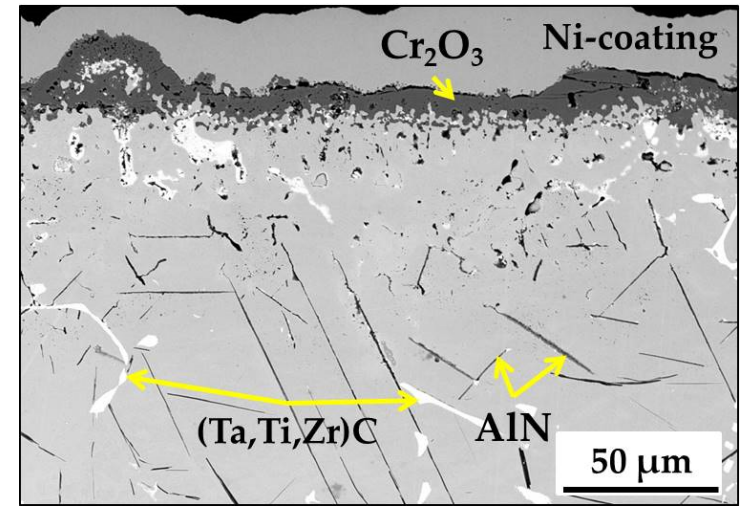

(c)

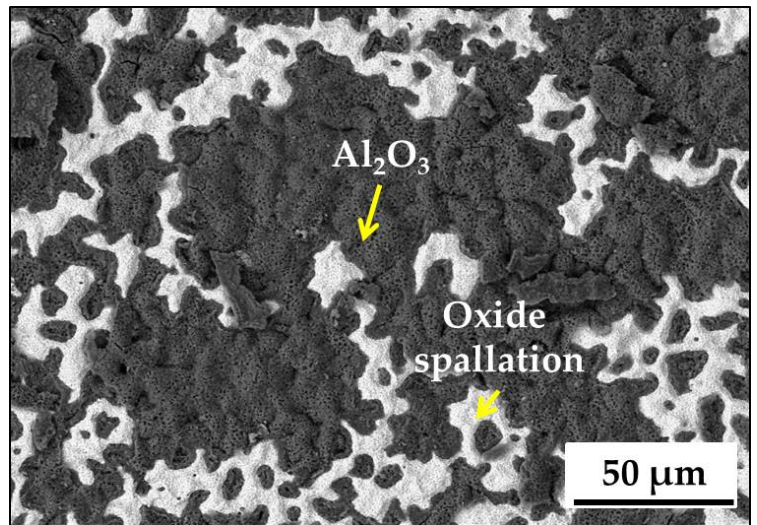

(b)

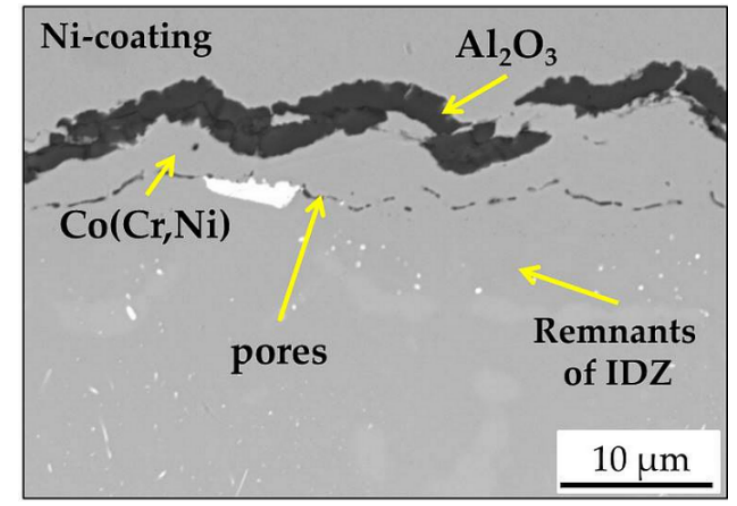

(d)

Figure 12. SEM/BSE images of surface of (a) MAR M-509 and (b) aluminized MAR M-509, with corresponding cross-sections of (c) MAR M-509 and (d) aluminized MAR M-509 after isothermal air oxidation at $1100{ }^{\circ} \mathrm{C}$ for $48 \mathrm{~h}$.

\subsubsection{Cyclic Oxidation Test}

The mass change curves obtained for uncoated MAR M-509 during cyclic air oxidation at $1100{ }^{\circ} \mathrm{C}$ showed an increase up to 10 cycle and a rapid mass loss after 10 cycles and at the end of the test, i.e., after 50 cycles (100 hot hours), the measured mass change is $-0.6 \mathrm{mg} \cdot \mathrm{cm}^{-2}$. In contrary, for aluminized MAR M-509, the constant increase in mass gain is found till the end of cyclic oxidation test. At the end of the test, the mass change measured for aluminized alloy is $1.6 \mathrm{mg} \cdot \mathrm{cm}^{-2}$ (Figure 13). Mass change curve obtained for aluminized MAR M-509 shown in Figure 13 does not show so clear change its slope as in Figure $7 \mathrm{~b}$. However, a macroscopic image of aluminized MAR M-509 after exposure revealed the occurrence of breakaway oxidation.

SEM/BSE images of the surface of oxidized uncoated MAR M-509 after cyclic oxidation test at $1100{ }^{\circ} \mathrm{C}$ showed that the alloy formed $\mathrm{Cr} / \mathrm{Co}$-mixed alloy on its surface. Moreover, a number of places indicating oxide scale spallation are observed (Figure 14a). SEM observation of the cross section of uncoated MAR M-509 confirmed the formation of $\mathrm{Cr} / \mathrm{Co}$ mixed oxide scale in the very outer surface. Below the outer oxide scale, the extensive formation of AlN is found (Figure 14c). Moreover, formation of light-grey precipitates, indicated by a red arrow, and dark-grey precipitates, indicated by a blue arrow, is observed (Figure 14c). In the cross-section of aluminized MAR M-509 (Figure 14), formation of an $\mathrm{Al}_{2} \mathrm{O}_{3}$ external oxide scale is found. The aluminide layer is identified as $\mathrm{Co}(\mathrm{Cr}, \mathrm{Ni})$. Moreover, no IDZ is observed. 


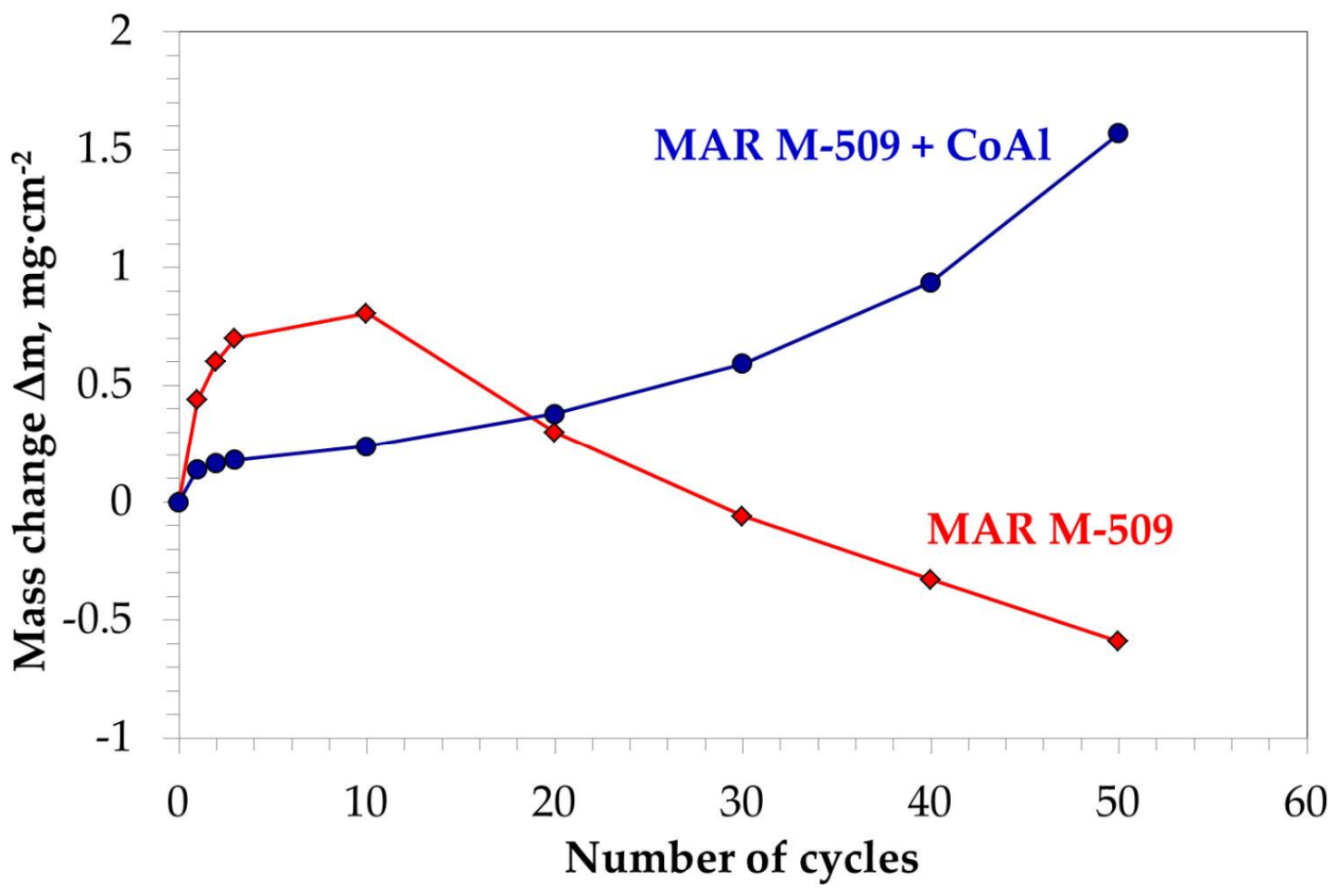

Figure 13. Mass change plot obtained during cyclic oxidation test at $1100{ }^{\circ} \mathrm{C}$ of aluminized MAR M-509 and reference alloy (uncoated MAR M-509).

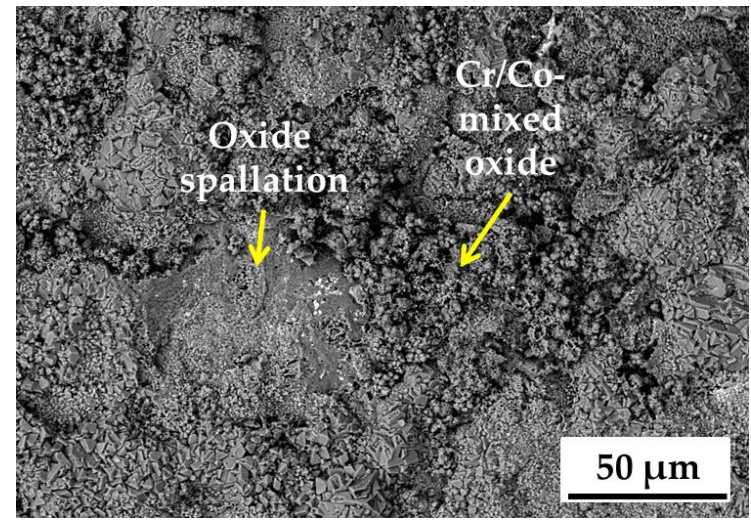

(a)

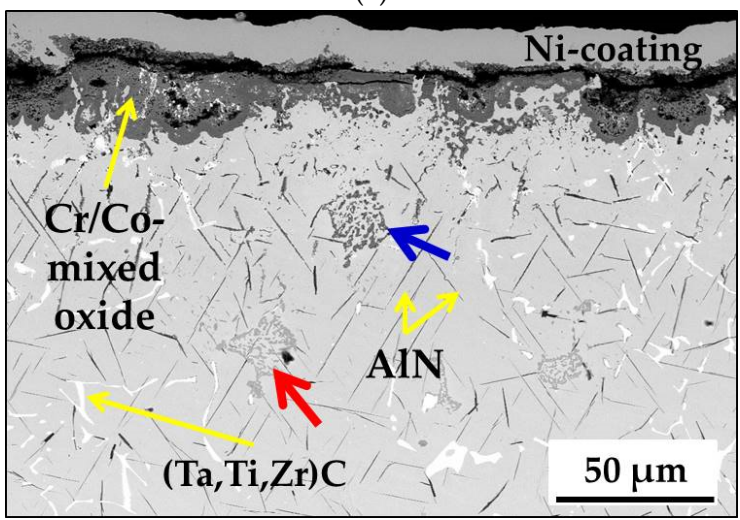

(c)

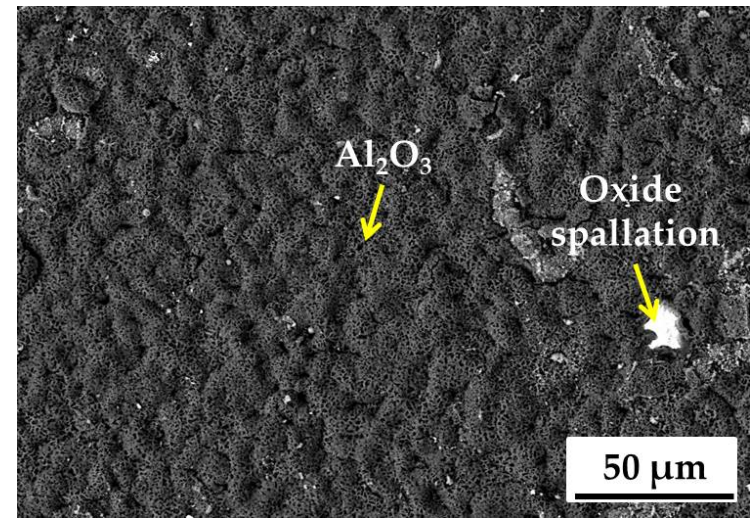

(b)

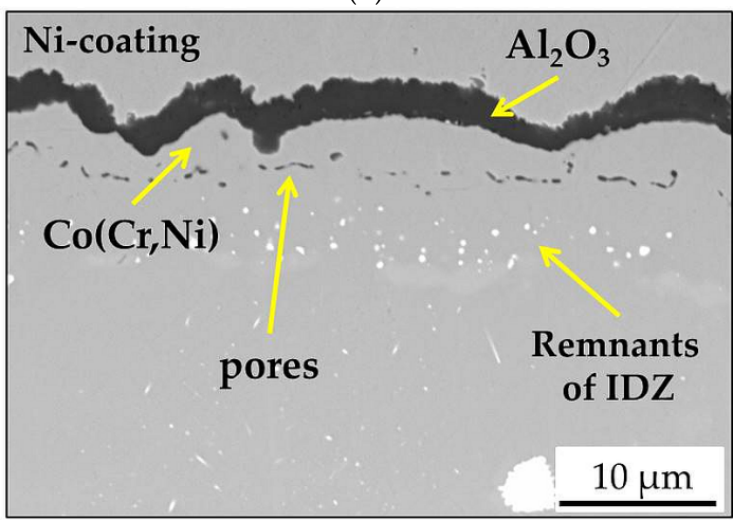

(d)

Figure 14. SEM/BSE images of surface of (a) MAR M-509 and (b) aluminized MAR M-509, with corresponding cross-sections of (c) MAR M-509 and (d) aluminized MAR M-509 after cyclic air oxidation at $1100{ }^{\circ} \mathrm{C}$ in air. 


\section{Discussion}

Considering the chemical composition of the studied Co-based alloy, namely MAR M-509, it is expected to form outer chromia scale, due to the relatively high Cr content, which is almost $23 \mathrm{wt} . \%$. The obtained results confirmed that the studied uncoated alloy forms chromia scale during isothermal exposure for a relatively short time (up to $50 \mathrm{~h}$ ) at both studied temperatures, i.e., at 1000 and $1100{ }^{\circ} \mathrm{C}$. The obtained value of the mass change for uncoated MAR M-509 during exposure at $1000{ }^{\circ} \mathrm{C}$ for $48 \mathrm{~h}$ is comparable to the mass changes of other chromia forming alloys [49,50]. Chromium oxide is treated as a protective oxide scale [51]; however, as is known from the literature, its growth rate is higher than that for alumina scale [52]. Such a trend was also observed in the present study. Namely, the value of instantaneous apparent parabolic oxidation rate constant $\mathrm{k}^{\prime} \mathrm{w}$ at the end of exposure at $1000^{\circ} \mathrm{C}$ of aluminized MAR M-509 was two orders of magnitude smaller than for uncoated MAR M-509. A similar trend was observed during exposure at $1100{ }^{\circ} \mathrm{C}$, where the difference between the value of $\mathrm{k}^{\prime} \mathrm{w}$ for aluminized and uncoated MAR M-509 was 1.5 orders of magnitude. Thus, slowly growing alumina scale increases the oxidation resistance of the studied Co-based superalloy MAR M-509. During cyclic exposure of uncoated MAR M-509, mainly $\mathrm{Cr}_{2} \mathrm{O}_{3}$-based oxide on its surface was formed. This leads to higher mass change as compared with coated sample. The faster oxide scale growth resulted in faster oxide scale thickening. As the result, the oxide scale formed on uncoated MAR M-509 reached a "critical oxide scale thickness" [53] after about 400 cycles of cyclic exposure. As consequence an oxide scale spallation occurred, which is visible in the mass change plot as a drop in mass change for uncoated MAR M-509 (Figure 7b). Such a drop in mass change was not observed for aluminized MAR M-509 due to the slower growth rate of $\mathrm{Al}_{2} \mathrm{O}_{3}$ in comparison with $\mathrm{Cr}_{2} \mathrm{O}_{3}$. However, as shown in the present study during the cyclic oxidation test, an increase in oxidation resistance by CVD aluminizing is limited. It was shown that the growth of alumina scale causes transformation of the phases present on the aluminide layer from $\mathrm{CoAl}$ into $\mathrm{Co}(\mathrm{Al})$ (i.e., Figure $6 \mathrm{~d}$ ). This transformation is caused by the depletion of $\mathrm{Al}$ from CoAl layer. The constant growth of $\mathrm{Al}_{2} \mathrm{O}_{3}$ led to reach so called "critical oxide thickness" [53], above which a crack formation and its propagation is the only way to relax the stresses within the formed oxide scale. This, in turn, combined with thermal cycling, caused oxide scale spallation and re-growth. The latter caused faster Al-depletion. Together with Al-depletion from the Co-aluminide layer, a diffusion of elements such as $\mathrm{Cr}$ and $\mathrm{Ni}$ from the underlying substrate into depleted Co-aluminide layer occurred. After depletion of Al-reservoir from the aluminide layer, another elements present in the layer becomes oxidized, such as $\mathrm{Co}, \mathrm{Cr}$ and $\mathrm{Ni}$, which finally leads to the occurrence of breakaway oxidation. The growth rate of $\mathrm{Co}-, \mathrm{Cr}$ - and Ni-oxide is much higher than for Al-oxide; thus, when the aforementioned elements become oxidized, a slope of mass change curve increases significantly. Such situation is visible in Figure 7b; namely, a change in mass change curve slope for aluminized MAR M-509 is observed at about 700 cycles. As shown during the cyclic oxidation test performed at $1000{ }^{\circ} \mathrm{C}$, the Al-reservoir present in the $10-\mu \mathrm{m}$ aluminide layer efficiently protected the alloy up to the 730th cycle, i.e., 1460 hot hours. Thus, aluminizing of MAR M-509 slowed down its oxidation kinetics by 2.5 times during exposure at $1000{ }^{\circ} \mathrm{C}$ and ensured the protection against the rapid oxidation up to $1460 \mathrm{~h}$. A similar trend was observed during exposure at $1100{ }^{\circ} \mathrm{C}$, namely, for uncoated MAR M-509, an oxide scale spallation was observed (mass loss in Figure 13), while for the aluminized sample, oxidation kinetics were decreased by a factor of 1.5. Further increasing of the oxidation resistance can be achieved by increasing the thickness of the CoAl layer.

As observed during the isothermal oxidation test, the uncoated MAR M-509 formed a relatively protective $\mathrm{Cr}_{2} \mathrm{O}_{3}$ oxide scale. However, in parallel, an intensive formation of nitrides in the deeper part of the alloy is also observed (e.g., Figure 6c, Figure 12c or Figure 14c). Since nitrides formation is relatively extensive and may affect the degradation mechanism of MAR M-509, it is worth to investigate and discuss this issue in more detail. From Figure 1, it is clear that in the alloy microstructure, a number of $\mathrm{TaCs}$ are found. 
SEM/EDS analysis of these carbides suggests that they also contain Ti and Zr. However, taking into account the fact that the EDS peaks for Ta, Ti and Zr partly overlap and in the literature these carbides in the MAR M-509 are identified as TaC, it is assumed that also in the present case, $\mathrm{TaC}$ are present in the alloy microstructure in the as-cast conditions. The results obtained in the present work showed that the carbides degrade during oxidation of uncoated MAR M-509 (see, e.g., Figure 6c, Figure 8c or Figure 12c). Moreover, as shown in Figure 14c, the new microstructural features are formed during exposure (the precipitates highlighted by red and blue arrows). The SEM/EDS elemental mapping of precipitate marked by red arrow shown in Figure 15 allows to identify this precipitate as $\mathrm{CrN}$. Moreover, it can be clearly seen that the needle-like-shaped precipitates are AlN (Figure 16). SEM/EDS point analysis (not shown here) revealed that the precipitate, marked by the blue arrow, is identified as oxidized $\mathrm{CrN}$. Note that the $\mathrm{CrN}$ precipitate is deeper than oxidized $\mathrm{CrN}$. To explain this phenomenon, the simplified calculations of diffusion coefficients for nitrogen and oxygen in pure Co were done for $1000{ }^{\circ} \mathrm{C}$ and $1100{ }^{\circ} \mathrm{C}$. At $1000{ }^{\circ} \mathrm{C}$ calculated diffusion coefficient for nitrogen was equal to $9.05 \times 10^{-9} \mathrm{~cm}^{2} \cdot \mathrm{s}^{-1}$, while for oxygen this was equal to $2.46 \times 10^{-10} \mathrm{~cm}^{2} \cdot \mathrm{s}^{-1}$. At $1100{ }^{\circ} \mathrm{C}$, calculated values for diffusion coefficient for nitrogen was equal to $5.98 \times 10^{-8} \mathrm{~cm}^{2} \cdot \mathrm{s}^{-1}$ and for oxygen this was equal to $1.63 \times 10^{-9} \mathrm{~cm}^{2} \cdot \mathrm{s}^{-1}$. The diffusion coefficients for oxygen and nitrogen were estimated from the available literature data, mainly from the solubility of oxygen in cobalt, parabolic rate constants of cobalt oxide [54], the diffusion coefficient of cobalt [55] and from Gibbs energy of oxygen and nitride [56]. The results clearly show that the diffusion coefficients for nitrogen are one order of magnitude higher than for oxygen at both temperatures; thus, due to this fact, during oxidation, a front of nitridation is expected before oxidation. In the other words, the nitride formation is expected at higher depths in the material and oxidation is expected to be placed closer to the surface of the material. This is illustrated in Figure 16, where the interface between nitridation and oxidation front is shown. The SEM/BSE image is taken in such positioning that the upper part of the image is closer to the surface of the studied material. Observation of the map for $\mathrm{N}$ and $\mathrm{O}$ clearly confirms the statements made above, namely that nitrogen is concentrated at the bottom part of the map (near the center of the sample), while oxygen is concentrated in the upper part (closer to sample surface). This means that the dark precipitates present in the near surface region are Al-oxides, while nitrides are present in the deeper part. An interesting observation was made in the near-carbide region, namely, near the interface between carbide and matrix, a nearly continuous grey phase has grown (Figure 17). Through these phases, an SEM/EDS line-scan was performed (Figure 18). The obtained results clearly showed that a co-enrichment of $\mathrm{Cr}$ and $\mathrm{N}$ is observed in the region of grey phases. The observed carbon content is at the level of its content in the matrix (Figure 18b). This suggests the formation of chromium nitrides or carbonitrides at the edge of $\mathrm{TaC}$. As the explanation, a preferential diffusion of nitrogen at the two phases boundary (in this case carbides and matrix) is assumed. Preferential diffusion of nitrogen via a two-phase boundary can be caused by the fact that such boundaries are called easy diffusion paths. On the other hand, there is no $\mathrm{Cr}$ in the carbide-it is present in the matrix. Preferential diffusion of nitrogen along the carbide/matrix interface causes local increase in nitrogen concentration. It is known that $\mathrm{Cr}$ is a strong nitride former; thus, due to the difference in chemical potential, Cr diffuses toward places with a higher nitrogen concentration (in this case the edge of the carbide) and forms stable nitride or carbonitride. Thus, the following mechanism for carbide degradation is proposed: carbides become nitrides at first and become subsequently oxidized. As shown in the present work, aluminizing of MAR M-509 successfully suppressed such a degradation mechanism at least until the beginning of breakaway oxidation. 


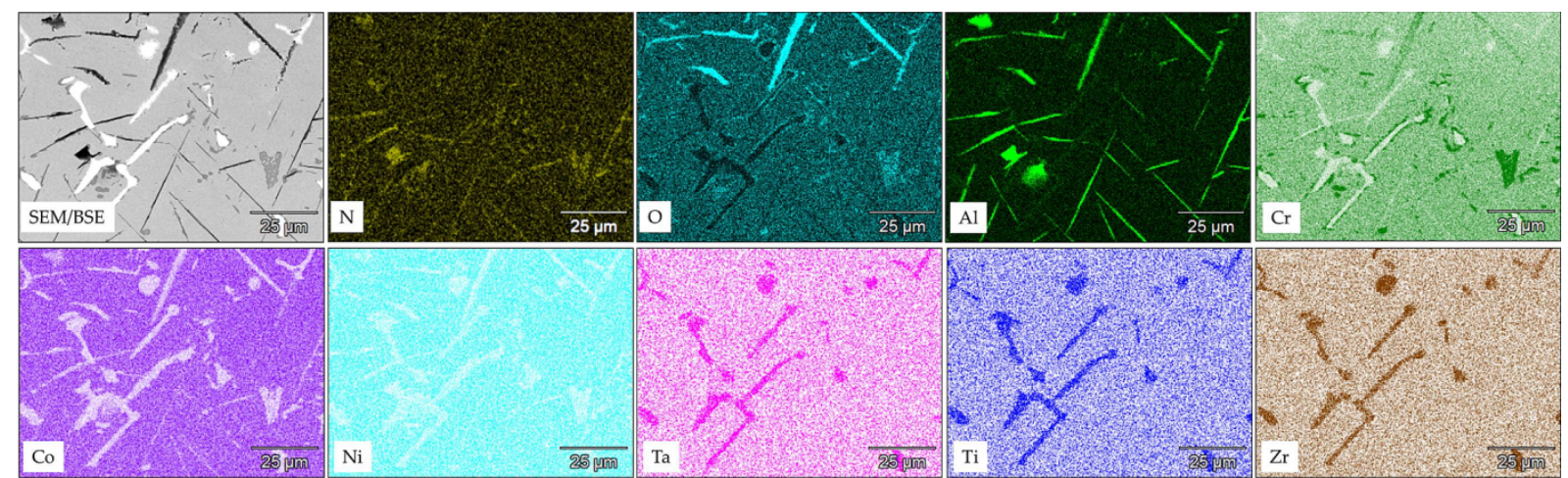

Figure 15. SEM/EDS elemental maps obtained in the region below the outer oxide scale formed on uncoated MAR M-509.

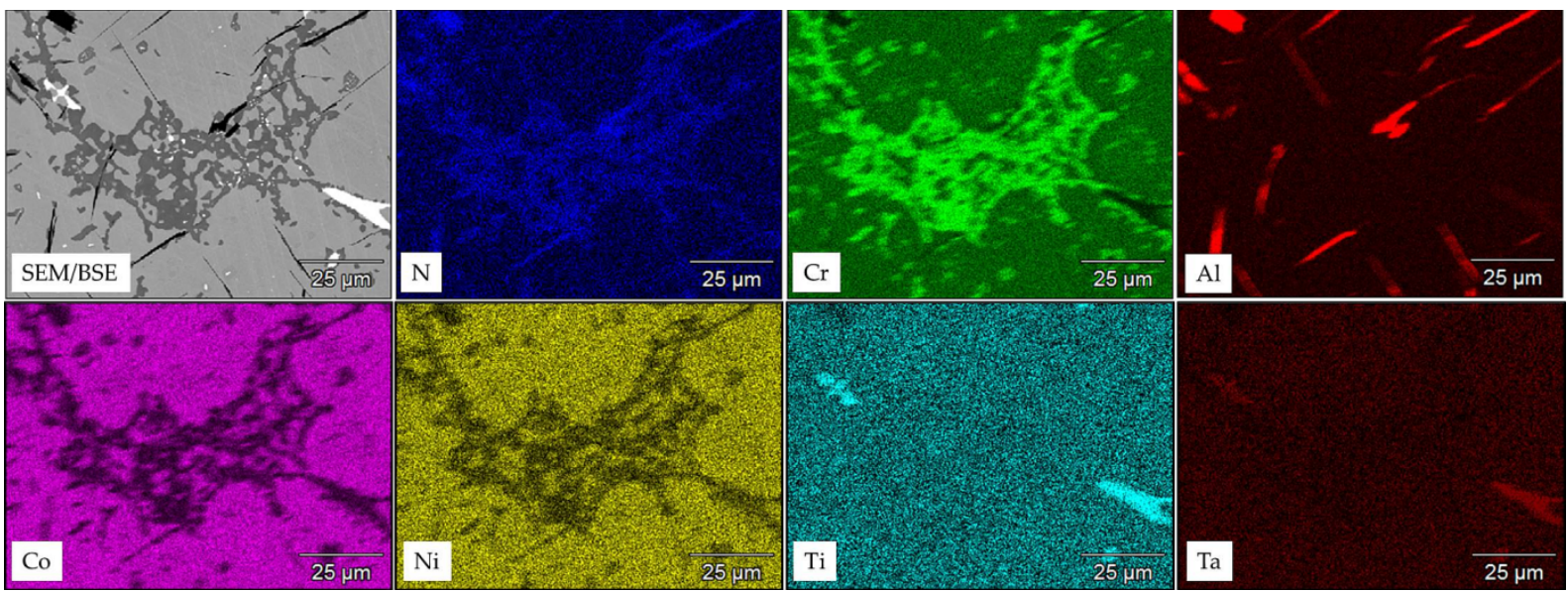

Figure 16. SEM/EDS elemental maps obtained in the region marked by a red arrow in Figure 15.

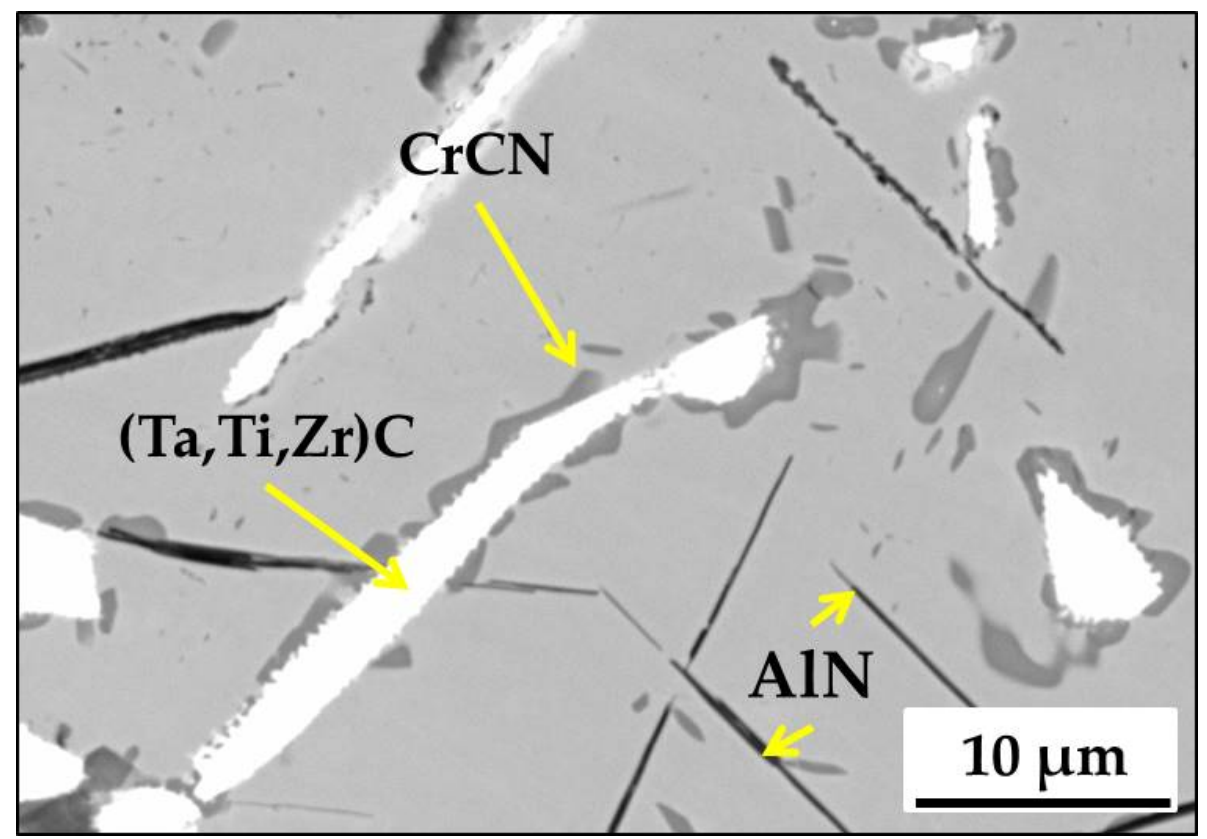

Figure 17. SEM/BSE image of the near-carbide region on uncoated MAR M-509 after cyclic oxidation at $1100{ }^{\circ} \mathrm{C}$. 


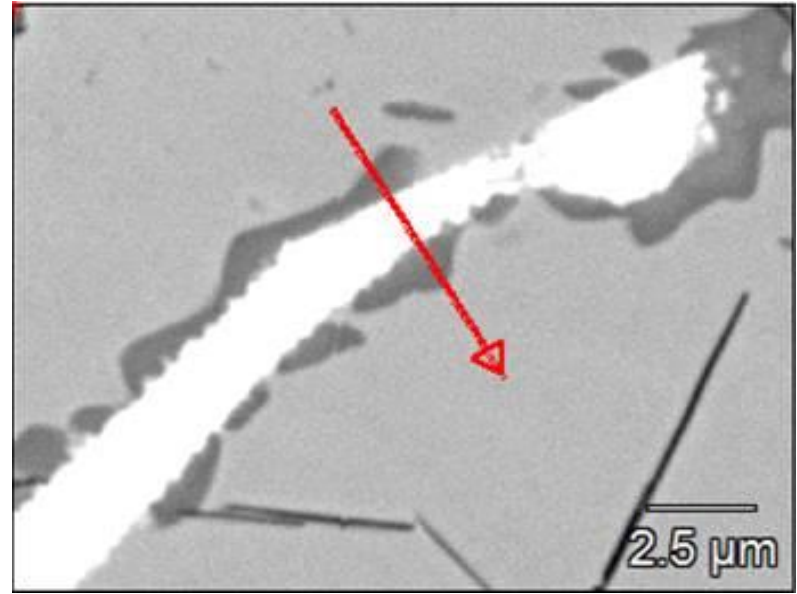

(a)

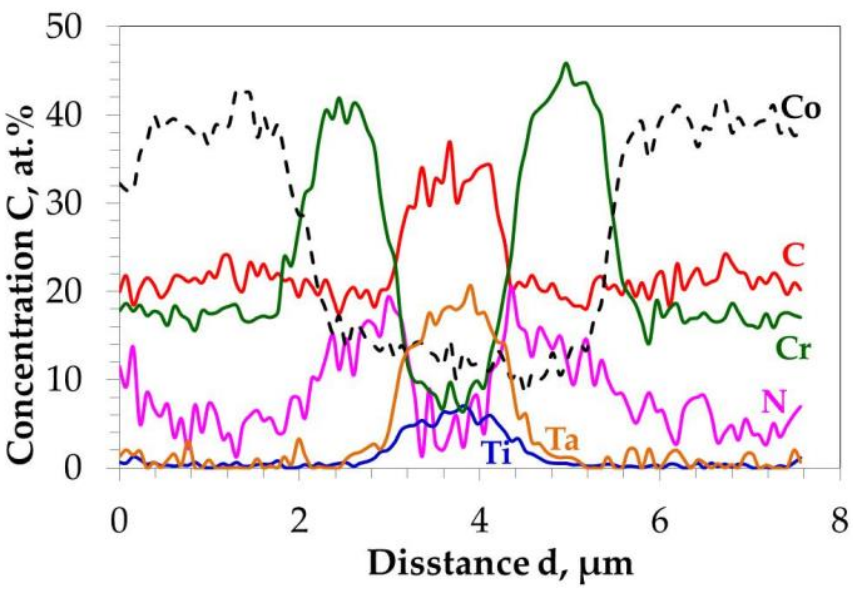

(b)

Figure 18. SEM/BSE image showing the location of the SEM/EDS line-scan through the carbide and near-carbide region (a) and the results of line-scan showing elements concentration expressed in at.\% (b).

\section{Conclusions}

In the present work, the influence of aluminizing of Co-based superalloy MAR M509 on its oxidation resistance was studied. Based on presented results, the following conclusions can be formulated:

1. During the short-term isothermal oxidation test, uncoated MAR M-509 forms an external oxide scale based on $\mathrm{Cr}_{2} \mathrm{O}_{3}$ accompanied by intensive formation of nitrides below the outer oxide scale. The formed nitrides were mainly identified as AlN.

2. It was observed that internal nitridation plays an important role in the material degradation mechanism due to significant participation in the destabilization of strengthening precipitates, which are $\mathrm{TaC}$ via the formation of $\mathrm{CrN}$ at the edge of carbides, which becomes oxidized at a later stage.

3. Aluminizing of MAR M-509 increases the oxidation resistance of MAR M-509 by decreasing the oxidation rate by a factor of 2.5 at $1000^{\circ} \mathrm{C}$ and 1.5 at $1100{ }^{\circ} \mathrm{C}$.

4. The aluminide CoAl layer on MAR M-509 suppressed the observed degradation mechanism, including nitridation until the occurrence of breakaway oxidation.

5. Aluminide layer with thickness of $10 \mu \mathrm{m}$ provided increased oxidation resistance of MAR M-509 up to 730 cycles, i.e., 1460 hot hours at $1000{ }^{\circ} \mathrm{C}$. At this stage, breakaway oxidation was observed.

6. It is proposed that a further increase in oxidation resistance of MAR M-509 can be achieved by increasing the thickness of the produced CoAl layer.

Author Contributions: Conceptualization, W.J.N.; methodology, W.J.N.; validation, W.J.N. and B.W.; formal analysis, W.J.N.; investigation, W.J.N., B.H. and K.O.; resources, W.J.N.; data curation, W.J.N. and B.W.; writing-original draft preparation, W.J.N.; writing-review and editing, W.J.N.; project administration, W.J.N.; funding acquisition, W.J.N. All authors have read and agreed to the published version of the manuscript.

Funding: This research was funded in whole or in part by the National Science Centre, Poland, Grant No. 2020/39/B/ST8/00334. For the purpose of Open Access, the author has applied a CC-BY public copyright license to any Author Accepted Manuscript (AAM) version arising from this submission.

Institutional Review Board Statement: Not applicable.

Informed Consent Statement: Not applicable.

Data Availability Statement: The data are available from the corresponding author upon reasonable request. 
Conflicts of Interest: The authors declare no conflict of interest. The funders had no role in the design of the study; in the collection, analyses or interpretation of data; in the writing of the manuscript, or in the decision to publish the results.

\section{References}

1. Schütze, M.; Quadakkers, W.J. Future Directions in the Field of High-Temperature Corrosion Research. Oxid. Met. 2017, 87, 681-704. [CrossRef]

2. Leng, W.; Pillai, R.; Naumenko, D.; Galiullin, T.; Quadakkers, W.J. Effect of substrate alloy composition on the oxidation behaviour and degradation of aluminide coatings on two Ni base superalloys. Corros. Sci. 2020, 167, 108494. [CrossRef]

3. Nowak, W.J.; Ochał, K.; Wierzba, P.; Gancarczyk, K.; Wierzba, B. Effect of Substrate Roughness on Oxidation Resistance of an Aluminized Ni-Base Superalloy. Metals 2019, 9, 782. [CrossRef]

4. Liu, H.; Li, S.; Jiang, C.Y.; Yu, C.T.; Bao, Z.B.; Zhu, S.L.; Wang, F.H. Preparation and oxidation performance of a low-diffusion Pt-modified aluminide coating with Re-base diffusion barrier. Corros. Sci. 2020, 168, 108582. [CrossRef]

5. Mahmoudi, H.; Hadavi, S.M.M.; Palizdar, Y. Characterization, growth kinetics and formation mechanism of aluminide coating by plasma paste aluminizing on IN738. Vacuum 2021, 184, 109968. [CrossRef]

6. Ghadami, F.; Aghdam, A.S.R.; Zakeri, A.; Saeedi, B.; Tahvili, P. Synergistic effect of $\mathrm{CeO}_{2}$ and $\mathrm{Al}_{2} \mathrm{O}_{3}$ nanoparticle dispersion on the oxidation behavior of MCrAlY coatings deposited by HVOF. Ceram. Int. 2020, 46, 4556-4567. [CrossRef]

7. Zhang, P.; Yuan, K.; Peng, R.L.; Li, X.; Johansson, S. Long-term oxidation of MCrAlY coatings at $1000{ }^{\circ} \mathrm{C}$ and an Al-activity based coating life criterion. Surf. Coat. Technol. 2017, 332, 12-21. [CrossRef]

8. Kilic, M.; Ozkan, D.; Gok, M.S.; Karaoglanli, A.C. Room- and high temperature Wear Resistance of MCrAlY Coatings Deposited by Detonation Gun (D-gun) and Supersonic Plasma Spraying (SSPS) Techniques. Coatings 2020, 10, 1107. [CrossRef]

9. Guo, D.; Zhao, L.; Jodoin, B. Cold spray for production of in-situ nanocrystalline MCrAlY coatings-Part II: Isothermal oxidation performance. Surf. Coat. Technol. 2021, 409, 126828. [CrossRef]

10. Nowak, W.J.; Kubaszek, T.; Góral, M.; Wierzba, B. Durability of underaluminized thermal barrier coatings during exposure at high temperature. Surf. Coat. Technol. 2020, 382, 125236. [CrossRef]

11. Ozgurluk, Y.; Doleker, K.M.; Ozkan, D.; Ahlatci, H.; Karaoglanli, A.C. Cyclic Hot Corrosion Failure Behaviors of EB-PVD TBC Systems in the Presence of Sulfate and Vanadate Molten Salts. Coatings 2019, 9, 166. [CrossRef]

12. Ebrahimzade, V.; Uchtmann, H.; Singheiser, L.; Küger, M.; Malzbender, J. Microstructure and cyclic oxidation behavior of APS TBC systems drilled with various laser methods. Surf. Coat. Technol. 2019, 378, 125018. [CrossRef]

13. Moskal, G.; Mikuśkiewicz, M.; Jasik, A. Thermal diffusivity measurement of ceramic materials used in spraying of TBC systems J. Therm. Anal. Calorim. 2019, 138, 4261-4269. [CrossRef]

14. Shi, H.; Tang, C.; Jianu, A.; Fetzer, R.; Weisenburger, A.; Steinbrueck, M.; Grosse, M.; Stieglitz, R.; Müller, G. Oxidation behavior and microstructure evolution of alumina-forming austenitic \& high entropy alloys in steam environment at $1200{ }^{\circ} \mathrm{C}$. Corros. Sci. 2020, 170, 108654. [CrossRef]

15. Lu, J.; Chen, Y.; Zhang, H.; Ni, N.; Li, L.; He, L.; Mu, R.; Zhao, X.; Guo, F. Y/Hf-doped AlCoCrFeNi high-entropy alloy with ultra oxidation and spallation resistance. Corros. Sci. 2020, 166, 108426. [CrossRef]

16. Osei-Agyemang, E.; Balasubramanian, G. Surface oxidation mechanism of a refractory high-entropy alloy. NPJ Mater. Degrad. 2019, 3, 20. [CrossRef]

17. Xu, J.; Kong, X.; Chen, M.; Wang, Q.; Wang, F. High-entropy FeNiCoCr alloys with improved mechanical and tribological properties by tailoring composition and controlling oxidation. J. Mater. Sci. Technol. 2021, 82, 207-213. [CrossRef]

18. Pan, Y.; Lu, X.; Hayat, M.D.; Yang, F.; Liu, C.C.; Li, Y.; Li, X.Y.; Xu, W.; Qu, H.H.; Cao, P. Effect of Sn addition on the hightemperature oxidation behavior of high $\mathrm{Nb}$-containing TiAl alloys. Corros. Sci. 2020, 166, 108449. [CrossRef]

19. Li, D.; Zhang, G.; Lu, G.; Wang, J.; Liu, C. Optimizing high-temperature oxidation behaviors of high-Nb-containing TiAl alloys by addition of boron. Corros. Sci. 2020, 177, 108971. [CrossRef]

20. Pan, Y.; Lu, X.; Liu, C.; Hui, T.; Zhang, C.; Qu, X. Sintering densification, microstructure and mechanical properties of Sn-doped high $\mathrm{Nb}$-containing TiAl alloys fabricated by pressureless sintering. Intermetallics 2020, 125, 106891. [CrossRef]

21. Lohfeld, S.; Schütze, M.; Böhm, A.; Güther, V.; Rix, R.; Scholl, R. Oxidation behaviour of particle reinforced MoSi2 composites at temperatures up to $1700^{\circ} \mathrm{C}$. Mater. Corros. 2015, 56, 250-258. [CrossRef]

22. Perepezko, J.H.; Harris, C. Oxidation of Mo-Si-B Alloys and Coatings in a Water Vapor Environment. Oxid. Met. 2021, 96, 323-332. [CrossRef]

23. Su, R.; Zhang, H.; Ouyang, G.; Liu, L.; Nachlas, W.; Cui, J.; Johnson, D.D.; Perepezko, J.H. Enhanced oxidation resistance of (Mo95W5)85Ta10(TiZr)5 refractory multi-principal element alloy up to $1300^{\circ} \mathrm{C}$. Acta Mater. 2021, 215, 117114. [CrossRef]

24. Makineni, S.K.; Singh, M.P.; Chattopadhyay, K. Low-Density, High-Temperature Co Base Superalloys. Annu. Rev. Mater. Res. 2021, 51, 187-208. [CrossRef]

25. Ruan, J.; Xu, W.; Yang, T.; Yu, Y.; Yang, S.; Luan, J.; Omori, T.; Wang, C.; Kainuma, R.; Ishida, K.; et al. Accelerated design of novel W-free high-strength Co-base superalloys with extremely wide $\gamma / \gamma^{\prime}$ region by machine learning and CALPHAD methods. Acta Mater. 2020, 186, 425-433. [CrossRef]

26. Feng, L.; Lv, D.; Rhein, R.K.; Goiri, J.G.; Titus, M.S.; Van der Ven, A.; Pollock, T.M.; Wang, Y. Shearing of $\gamma^{\prime}$ particles in Co-base and Co-Ni-base superalloys. Acta Mater. 2018, 161, 99-109. [CrossRef] 
27. Weiser, M.; Galetz, M.C.; Zschau, H.E.; Zenk, C.H.; Neumeier, S.; Göken, M.; Virtanen, S. Influence of Co to Ni ratio in $\gamma^{\prime}-$ strengthened model alloys on oxidation resistance and the efficacy of the halogen effect at $900{ }^{\circ} \mathrm{C}$. Corros. Sci. 2019, $156,84-95$. [CrossRef]

28. Pollock, T.M.; Dibbern, J.; Tsunekane, M.; Zhu, J.; Suzuki, A. New Co-based $\gamma-\gamma^{\prime}$ high-temperature alloys. JOM 2010, 62, 58-63. [CrossRef]

29. Bond, A.P.; Uhlig, H.H. Corrosion Behavior and Passivity of Nickel-Chromium and Cobalt-Chromium Alloys. J. Electrochem. Soc. 1960, 107, 488. [CrossRef]

30. Kocijan, A.; Milošev, I.; Pihlar, B. Cobalt-based alloys for orthopaedic applications studied by electrochemical and XPS analysis. J. Mater. Sci. Mater. Med. 2004, 15, 643-650. [CrossRef]

31. Migas, D.; Moskal, G.; Myalska, H.; Mikuszewski, T. The effect of alloying elements on oxide scale spallation of multicomponent Co-based superalloys. Corros. Sci. 2021, 192, 109787. [CrossRef]

32. Weiser, M.; Chater, R.J.; Shollock, B.A.; Virtanen, S. Transport mechanisms during the high-temperature oxidation of ternary $\gamma / \gamma^{\prime}$ Co-base model alloys. NPJ Mater. Degrad. 2019, 3, 33. [CrossRef]

33. Kubacka, D.; Weiser, M.; Spiecker, E. Early stages of high-temperature oxidation of Ni- and Co-base model superalloys: A comparative study using rapid thermal annealing and advanced electron microscopy. Corros. Sci. 2021, 191, 109744. [CrossRef]

34. Stewart, C.A.; Murray, S.P.; Suzuki, A.; Pollock, T.M.; Levi, C.G. Accelerated discovery of oxidation resistant CoNi-base $\gamma / \gamma^{\prime}$ alloys with high L12 solvus and low density. Mater. Des. 2020, 189, 108445. [CrossRef]

35. Rosas, A.O.P.; Epler, M.E.; Kernion, A.J.; Forsik, S.A.J.; Colombo, G.A.; Wang, T.; Zhou, N. High-Temperature Oxidation Behavior of a Novel Co-Base Superalloy. Metall. Mater. Trans. A 2018, 49, 4058-4069. [CrossRef]

36. Wang, Y.Q.; Sayre, G. Synthesis of simple and platinum-modified aluminide coatings on cobalt (Co)-base superalloys via a vapor phase aluminizing process. Surf. Coat. Technol. 2008, 203, 256-263. [CrossRef]

37. Lee, J.W.; Kuo, Y.C. Cyclic oxidation behavior of a cobalt aluminide coating on Co-base superalloy AMS 5608. Surf. Coat. Technol. 2005, 200, 1225-1230. [CrossRef]

38. Liu, P.S.; Liang, K.M.; Zhou, H.Y.; Gu, S.R.; Sun, X.F.; Guan, H.R.; Jin, T.; Yang, K.N. Cyclic oxidation behavior of aluminide coatings on the Co-base superalloy DZ40M. Surf. Coat. Technol. 2001, 145, 75-79. [CrossRef]

39. Mróz, M.; Orłowicz, W.; Tupaj, M. Evaluation of fractures in MAR-M509 alloy samples after fatigue strength tests. Arch. Foundry Eng. 2010, 10, 115-118.

40. Franclois, M.; Rémy, L. thermal-mechanical fatigue of mar-m 509 superalloy. comparison with low-cycle fatigue behaviour. Fatigue Fract. Eng. Mater. Struct. 1991, 14, 115-129. [CrossRef]

41. Baufeld, B.; Tzimas, E.; Müllejans, H.; Peteves, S.; Bressers, J.; Stamm, W. Thermal-mechanical fatigue of MAR-M 509 with a thermal barrier coating. Mater. Sci. Eng. A 2001, 315, 231-239. [CrossRef]

42. Galiullin, T.; Gobereit, B.; Naumenko, D.; Buck, R.; Amsbeck, L. Neises-von Puttkamer, M.; Quadakkers, W.J. High temperature oxidation and erosion of candidate materials for particle receivers of concentrated solar power tower systems. Sol. Energy 2019, 188, 883-889. [CrossRef]

43. Berthod, P.; Gomis, J.P.; Medjahdi, G.; Panteix, P.J.; Aranda, L. A study of the dependence on the Co and Ni proportions of the oxidation at elevated temperature of TaC-strengthened $\{\mathrm{Ni}$ and $\mathrm{Co}\}$-based cast superalloys. Mater. Chem. Phys. 2020, 251, 123088. [CrossRef]

44. Pfeifer, J.P.; Holzbrecher, H.; Quadakkers, W.J.; Speier, J. Quantitative analysis of oxide films on ODS-alloys using MCs+-SIMS and e-beam SNMS. J. Anal. Chem. 1993, 346, 186-191. [CrossRef]

45. Quadakkers, W.J.; Elschner, A.; Speier, W.; Nickel, H. Composition and growth mechanisms of alumina scales on FeCrAl-based alloys determined by SNMS. Appl. Surf. Sci. 1991, 52, 271-287. [CrossRef]

46. Nowak, W.J. Characterization of oxidized Ni-based superalloys by GD-OES. J. Anal. At. Spectrom. 2017, 32, 1730-1738. [CrossRef]

47. Nowak, W.J.; Wierzba, B. Effect of Surface Treatment on High Temperature Oxidation Behavior of IN 713C. J. Mater. Eng. Perform. 2018, 27, 5280-5290. [CrossRef]

48. Nowak, W.J.; Siemek, K.; Ochał, K.; Kościelniak, B.; Wierzba, B. Consequences of different mechanical surface preparation of Ni-base alloys during high temperature exposure. Materials 2020, 13, 3529. [CrossRef]

49. Essuman, E.; Meier, G.H.; Zurek, J.; Hänsel, M.; Norby, T.; Singheiser, L.; Quadakkers, W.J. Protective and non-protective scale formation of $\mathrm{NiCr}$ alloys in water vapour containing high- and low- $\mathrm{pO}_{2}$ gases. Corr. Sci. 2008, 50, 1753-1760. [CrossRef]

50. Zurek, J.; Young, D.J.; Essuman, E.; Hänsel, M.; Penkalla, H.J.; Niewolak, L.; Quadakkers, W.J. Growth and adherence of chromia based surface scales on Ni-base alloys in high- and low- $\mathrm{pO}_{2}$ gases. Mater. Sci. Eng. A 2008, 477, 259-270. [CrossRef]

51. Giggins, C.S.; Pettit, F.S. Oxidation of Ni-Cr-Al alloys between $1100{ }^{\circ} \mathrm{C}$ and $1200{ }^{\circ} \mathrm{C}$. Solid. State Sci. 1971, 118, $1782-1790$.

52. Young, D.J. High Temperature Oxidation and Corrosion of Metals, 2nd ed.; Elsevier: Cambridge, UK, 2008.

53. Hou, P.Y.; Cannon, R.M. Spallation Behavior of Thermally Grown Nickel Oxide on Nickel. Oxid. Met. 2009, 71, 237-256. [CrossRef]

54. Mrowec, S.; Werber, T. Korozja Gazowa; WYDAWNICTWO “ŚLSK”: Katowice, Poland, 1965.

55. Nix, F.C.; Jaumot, F.E., Jr. Self-Diffusion in Cobalt. Phys. Rev. 1951, 82, 72. [CrossRef]

56. Barin, I. Thermochemical Data of Pure Substances; VCH: Weinheim, Germany, 1995. 